\title{
Explaining Africa's Rapid Population Growth, 1950 to 2020: Trends, Factors, Implications, and Recommendations
}

\author{
Amadu Jacky Kaba \\ Department of Sociology, Anthropology, and Social Work, Seton Hall University, South Orange, NJ, USA \\ Email: amadu.kaba@shu.edu
}

How to cite this paper: Kaba, A. J. (2020). Explaining Africa's Rapid Population Growth, 1950 to 2020: Trends, Factors, Implications, and Recommendations. Sociology Mind, 10, 226-268.

https://doi.org/10.4236/sm.2020.104015

Received: September 5, 2020

Accepted: October 27, 2020

Published: October 30, 2020

Copyright $\odot 2020$ by author(s) and Scientific Research Publishing Inc. This work is licensed under the Creative Commons Attribution International License (CC BY 4.0).

http://creativecommons.org/licenses/by/4.0/

\section{(c) (i) Open Access}

\begin{abstract}
This study examines the rapid growth of Africa's population in the post-World War II era. The study finds that Africa's population increased by over 1 billion, from 228.7 million in 1950 to 1.341 billion in 2020: 431 million in Eastern Africa; 404 million in Western Africa; 247.5 million in Northern Africa; 193.5 million in Middle Africa; and 64.5 million in Southern Africa. There are four countries in Africa with populations of 100 million or more: 214 million in Nigeria; 108 million in Ethiopia; 104 million in Egypt; and 101.8 million in the Democratic Republic of Congo. Of the 1.341 billion people in Africa in 2020, 755.92 (56.4\%) million are aged 24 and younger; and 533.5 (39.8\%) million are under the age of 15 . Some factors cited for this phenomenon are: high birth rates; high fertility rates; childbirth at a young age; low rates of contraceptive use; decline in infant mortality rates; decline in overall deaths rates; decline in maternal mortality rates; increase in life expectancy; and decline in HIV/AIDS related deaths. Some implications cited as a result of this phenomenon include increase in GDP and GDP per Capita in Africa; increase in the numbers of billionaires and millionaires in Africa; increase in political influence of African nations in the international community; and increase in the number of educated Africans, including those enrolled in college and college graduates. Finally, the study recommends that African nations should make the African Union a fully-fledged federal entity to be responsible for providing healthcare for the entire continent. The African Union should also represent all member states in the international community, including negotiating trade contracts or agreements.
\end{abstract}

\section{Keywords}

African Population, Population Growth, Trends, Demography, GDP, Billionaires, Millionaires 


\section{Introduction/Background}

The total population of the world has increased massively in the post-World War II era. For example, on July 1, 1950, the total population of the world was 2.536 billion ("World Population Prospects: The 2017 Revision", 2018). By 2020, it increased to 7.684 billion ("U.S. and World Population Clock", 2020). Although Asia as a continent has a majority of the world's total population in 2020, estimated at 4.6 billion (Khokhar \& Kashiwase, 2015), the continent of Africa has contributed substantially to the rapid increase in the world's population during this period. For example, in 1950, the total population of Africa was 228.7 million ("World Population Prospects: The 2017 Revision", 2018). By July 1, 2020, that figure increased by over a billion people to 1.341 billion (Compiled and computed from the CIA World Factbook, 2020). Africa's total population increased by 176.3 million people from July 1, 2015 to July 1, 2020. According to Weil (2008): "While world population as a whole has grown by a factor of 2.6 since 1950, in Africa it grew by a factor of 4.3. In 2005, 753 million people lived in sub-Saharan Africa.... between 2005 and 2050, the population of Africa will increase by a factor of 2.3 " (p. 16).

However, Africa's rapid population growth is somewhat different from other continents or regions, with massive numbers of young people under the age of 15 , and a very small proportion of people aged 65 and over. For example, of the 1.341 billion people in Africa in July 2020, 533.5 million (39.8\%) were under the age of 15 , and $3.3 \%$ (or 44.5 million) were aged 65 and over. The proportion of people in the world under the age of 15 in July 2020 was $25.33 \%$, and the proportion aged 65 and over was 9.5\% (Compiled and computed from the CIA World Factbook, 2020; also see Badenhorst, 1951; Kaba, 2016: p. 15; Martin, 1953).

Africa's massive population growth in such a short period of time has also come with many interrelated challenges and opportunities. Some of the challenges include producing sufficient food to feed such a large number of people, providing healthcare, environmental degradation, increasing scarcity of fresh water, emigration of millions of Africans out of the continent, and providing adequate education to the hundreds of millions of young people living inside the continent (Abate, 1978: p. 15; Ashton, 2002; Bremner, 2012; Ezeh et al., 2012; "John C. Caldwell on Major Questions in African Demographic History", 2016; Kaba, 2006, 2009a, 2014; Mazzucato \& Niemeijer, 2002; Mwichabe, 2014: p. 412; Rovin et al., 2013: pp. 15-16; Zuberi et al., 2003: pp. 472-473). As Ezeh et al. (2012) point out:

"Rapid population growth puts pressure on public services and infrastructure. Low-income countries tend to have limited public services (i.e., health care, education, municipal), an insufficiently trained labour force, and weak infrastructure (e.g., roads, water supply, electricity). Governments' attempts to overcome these problems are made more difficult by the rapidly growing number of people that need to be served. New services, new school gra- 
duates, and new infrastructure have to be created at a rate of $2 \%-4 \%$ per year simply to maintain conditions without deterioration" (p. 143; also see Abate, 1978: p. 15).

Scholars have utilized many concepts or theories to explain these challenges discussed above. Some of these theoretical or conceptual perspectives include: the overlapping generations framework (Mountford \& Rapoport, 2016), the concept of human security (Kruys, 2008), smart growth (Arku, 2009), demographic transitions (Iliffe, 1989), fertility transition (Mason, 1997; Zinkina \& Korotayev, 2014), Malthusian theory of population (Ewugi \& Yakubu, 2012; Rashid, 1987), and preference theory (Hakim, 2003).

Mason (1997) discusses the concept of fertility transitions by describing it as: “... long-term declines in the number of children from four or more per woman to two or fewer" (p. 443). One of six theories of fertility transitions explained by Mason (1997) is the classic demographic transition theory, which: “... attributes fertility decline to changes in social life that accompany, and are presumed to be caused by, industrialization and urbanization. These changes initially produce a decline in mortality, which sets the stage for-or by itself may bring about-fertility decline by increasing survival of children and, hence, the size of families" (p. 444). Arku (2009) points out that the concept of smart growth “... calls for focusing future growth on existing built-up areas to establish a compact, efficient, and environmentally sensitive pattern of urban development that provides people with various transportation systems and a range of housing and employment choices" (p. 255). According to Ewugi and Yakubu (2012), the Malthusian theory of population posits that increases in population "... at geometric ratio while food production increases at arithmetic ratio. It goes further that if the situation is left unchecked, at a time, population will grow beyond food supply" (pp. 198-199). The late Thomas Malthus (1766-1834), who was a clergyman and a mathematician, suggested that instead of controlling rapid population growth through “"positive' checks.... death via war, malnutrition and pestilence", or " "preventive" checks-limit to birth via infanticide, abortion, contraception... the best form of population control is the moral restraint which meant late marriage, remaining chaste for the meantime-the only option to save people and their communities from 'rags and squalid poverty'. In other words, poverty was an inevitable result of rapid population growth" (pp. 198-199).

Some of the opportunities resulting from Africa's rapid population growth include: increase in the Gross Domestic Product (GDP) and GDP per capita of most African nations; increasing numbers of millionaires and billionaires on the continent and Africans in the diaspora; the rise of a visible middle class in Africa and abroad; increase in the number of high school and college graduates in Africa; increase in political influence of Africa in the international community, including at the United Nations; gradual inheritance of land or territory outside of Africa; and substantial amounts of diaspora remittances to Africa (Kaba, 
2005, 2014).

This study examines the rapid population growth in Africa from 1950 to 2020. The study begins by presenting data on trends in Africa's rapid population growth, with a demographic breakdown of figures for 2020 for the five regions of Africa. Next, the study presents some factors responsible for this massive population growth in Africa in the post-World War II era. Next, the study presents some positive implications of this phenomenon. Finally, the study presents a number of recommendations for managing this phenomenon. One important recommendation is for member nations of the African Union to make that entity a fully-fledged state, with a more powerful central government in order to represent all member states in the international community.

\section{Data on Trends in Africa's Rapid Population Growth, 1950 to 2020}

Although Asia has over three billion people more than the total population of Africa, within the past two decades, Africa has been contributing a substantial proportion of the 80 million people added annually to the world population (Kaba, 2007: p. 78). In fact, according to Khokhar and Kashiwase (2015), in the year 2100, Asia's population is projected to increase to 4.89 billion and Africa's population is projected to increase to 4.39 billion. Abate (1978) points out that Africa's population increased from 273 million (9.1\% of world total) in 1960 to 401 million ( $10.1 \%$ of world total) in 1975 , to 811 million ( $13.1 \%$ of world total) in 2000 (p. 14). Ezeh et al. (2012) point out that Africa's total population will increase from 1.02 billion in 2010 to 2.19 billion in 2050, a $114.4 \%$ increase during that period (p. 145; also see Abate, 1978: p. 16).

For sub-Saharan Africa, Ezeh et al. (2012) point out that its population will increase from 0.86 billion in 2010 to 1.96 billion in 2050, a 129\% increase during that period. For the world as a whole, the figures are 6.9 billion to 9.31 billion, respectively, a 35\% increase during that period (p. 145; also see "The 2015 Revision of the UN's World Population Projections", 2015: pp. 257-259; Zuberi et al., 2003: pp. 468-469). The total population of sub-Saharan Africa is projected to be 4 billion at the end of the twenty-first century (Casterline, 2017: p. 5). According to Clapham (2006): "Sub-Saharan Africa stands firmly at one end of the demographic and development continuum. Demographically, it ranks highest in the world in its recent level of population increase, at 2.5 percent per annum over the period 1990-2003, though this marks a decrease from the 2.9 percent of the previous decade" (p. 96). According to Table A2(a)-(f), in 2020, the average population growth rate in Africa was 2.5 percent. The following African nations had population growth rates of 3\% or higher: $3.66 \%$ in Niger; $3.43 \%$ in Angola; 3.4\% in Benin; 3.34\% in Uganda; 3.3\% in Malawi; 3.3\% in Mayotte (2010 estimate); and 3.18\% each in Chad and the Democratic Republic of Congo.

There are some visible or significant demographic differences among the five regions of Africa, with Northern and Southern Africa having some paradoxical 
differences compared with the other three regions of the continent. While Africa's population increased from 228.7 million in 1950 to 1.341 billion in 2020, Eastern, Western and Middle Africa are the three regions growing more rapidly in recent decades. Utilizing the United Nations Statistics Division's classifications of the five regions of Africa (Eastern, Middle, Northern, Southern and Western Africa, see Appendix A), Kaba (2007) finds that in July 2006, of the 910.84 million people in Africa, Eastern Africa had the highest proportion, with 284 million (31.2\%); Western Africa, with 260.9 million (28.6\%); Northern Africa, with 202.6 million (22.2\%); Middle Africa, with 112.2 million (12.3\%); and Southern Africa, with 51 million (5.6\%). (pp. 78-80). According to Table A1(a)-(f), of the five regions in Africa, Eastern Africa has the highest proportion of Africa's 1.341 billion population, 32.2\% (431 million people); Western Africa, 30.2\% (404.14 million people); Northern Africa, 18.5\% (247.5 million people); Middle Africa, 14.5\% (193.5 million people); and Southern Africa, 4.9\% (64.5 million people) (Table A1(a)-(f)).

Abate (1978) points out that in 1977, there were 5 countries in Africa with populations over 25 million (44.2\% of Africa's total) (Nigeria, Egypt, Ethiopia, South Africa, and Zaire/Democratic Republic of Congo); 7 countries had populations of $10-20$ million (25\% of total); 12 countries had populations of 5 10 million (18.5\% of total); 14 countries had populations of 1 - 5 million $(9.7 \%$ of total); and 12 countries had populations of less than 1 million (1.5\% of total) (p. 14). In July 2006, the top 10 most populous countries in Africa were:

Nigeria, with 131.9 million (14.5\% of total); Egypt, 78.9 million (8.7\%); Ethiopia, 74.8 million (8.2\%); the Democratic Republic of Congo, 62.7 million (6.9\%); South Africa, 44.2 million (4.9\%); Sudan, 41.2 million (4.5\%); Tanzania, 37.4 million (4.1\%); Kenya, 34.7 million (3.8\%); Morocco, 33.2 million (3.6\%); and Algeria, 32.9 million (3.6\%) (Kaba, 2007: pp. 78-80).

In 2020, there were four countries in Africa with at least 100 million people: Nigeria, 214 million (16\% of Africa's total); Ethiopia, 108.1 million (8.1\%); Egypt, 104.1 million (7.8\%); and the Democratic Republic of Congo, 101.8 million (7.6\%). These four countries accounted for 39.4\% (528 million) of Africa's total population. Egypt's population grew from 21.2 million in 1950 to 42.6 million in 1980, to 81.7 million in 2008 (Zinkina \& Korotayev, 2013: p. 23). There were three countries with populations in the 50 million range: Tanzania, 58.6 million (4.4\%); South Africa, 56.5 million (4.2\%); and Kenya, 53.5 million (4\%). These three countries accounted for 12.6\% (168.6 million) of Africa's total population.

There are three countries with populations in the 40 million rage: Sudan, 45.6 million (3.4\%); Uganda, 43.3 million (3.2\%); and Algeria, 43 million (3.2\%). These three countries accounted for 9.8\% (131.9 million) of Africa's total population. There are three countries with populations in the 30 million range: Morocco, 35.6 million (2.7\%); Angola, 32.5 million (2.4\%); and Mozambique, 30.1 million (2.2\%). These three countries accounted for 7.3\% (98.2 million) of Afri- 
ca's total. There are seven countries with populations in the 20 million range: Ghana, 29.3 million (2.2\%); Cameroon, 27.8 million (2.1\%); Cote d'Ivoire, 27.5 million (2.1\%); Madagascar, 27 million (2\%); Niger 22.8 (1.7\%); Malawi, 21.2 million (1.6\%); and Burkina Faso, 20.8 million (1.6\%). These seven countries accounted for $13.2 \%$ (176.4 million) of Africa's total population.

There are 12 countries with populations of 10 million to under 20 million: Mali, 19.6 million (1.5\%); Zambia, 17. 4 million (1.3\%); Chad, 16.9 million (1.3\%); Senegal, 15.7 million (1.2\%); Zimbabwe, 14.6 million (1.1\%); Benin, 12.9 million (1\%); Rwanda, 12.7 million (1\%); Guinea, 12.5 million (0.9\%); Burundi, 11.9 million (0.9\%); Somalia, 11.8 million (0.9\%); Tunisia, 11.7 million $(0.9 \%)$; and South Sudan, 10.6 million (0.8\%). These 12 countries accounted for $12.6 \%$ (168.3 million) of Africa's total population. There are 7 countries with populations ranging from 5 million to under 10 million: Togo, 8.6 million (0.64\%); Libya, 6.9 million (0.5\%); Sierra Leone, 6.6 million (5\%); Eritrea, 6.1 million (0.5\%); Central African Republic, 5.99 million (0.45\%); Republic of Congo, 5.3 million (0.4\%); and Liberia, 5.1 million $(0.38 \%)$. These 7 countries accounted for $3.3 \%$ (44.59 million) of Africa's total population.

There are 9 countries with populations ranging from 1 million to under 5 million: Mauritania, 4 million (0.3\%); Namibia, 2.6 million (0.2\%); Botswana, 2.3 million (0.17\%); Gabon, 2.2 million (0.16\%); The Gambia, 2.2 million (0.16\%); Lesotho, 1.97 (0.15\%); Guinea-Bissau, 1.9 million (0.14\%); Mauritius, 1.4 million (0.1\%); and eSwatini, 1.1 million (0.08\%); These 9 countries accounted for 19.67 million (1.5\%) of Africa's total population.

Finally, there are 10 countries or entities with populations under 1 million: Djibouti, 921,804 (0.007\%); Comoros, 846,281 (0.006\%); Equatorial Guinea, 836,178 (0.0063\%); Reunion, 787,584 (0.006\%, 2006 estimate); Western Sahara, 652,271 (0.0049\%); Cabo Verde, 583,255 (0.0043\%); Sao Tomi \& Principe, 211,122 (0.0016\%); Mayotte, 231,139 (0.0018\%, 2010 estimate); Seychelles, 95,981 (0.00072\%); and Saint Helena, 7862 (0.000059\%). These 10 countries and entities accounted for $0.4 \%$ (5.2 million) of Africa's total population (Table A1(a)-(f)).

Among the continents of the world, Africa has the highest proportions of countries with populations under age 15 or median age of 20 years or less. However, a very small proportion of Africa's population is aged 65 and over. This trend has continued in the past five decades. For example, in 1977, 44\% of Africa's total population was under the age of 15; 3\% was 65 and over; in Western Europe, the figures were 23\% and 12\% respectively (Abate, 1978: p. 15; also see Martin, 1953: pp. 183-187). In 2020, of the 1.341 billion people in Africa, 533.5 million (39.8\%) were under the age of $15: 18.1 \%$ were aged $15-24,31.8 \%$ were aged 25 - 54, 4.5\% were aged 55 - 64, and 3.3\% were aged 65 and over. Among the five regions of Africa, higher proportions of people are under 15 years old, and smaller proportions are 65 years and older in Western, Middle, and Eastern Africa. For example, of the 1.341 billion people in Africa in 2020, 
$45.6 \%$ were under the age of $15,19.4 \%$ were aged 15 - 24, 26\% were aged 25 - 54, $5.6 \%$ were aged 55 - 64, and 1.9\% were aged 65 and over in Middle Africa; $42 \%$, $20 \%, 30 \%, 4.1 \%$, and $3.3 \%$ respectively, in Western Africa; $40.6 \%, 18.6 \%, 31 \%$, $3.8 \%$, and $3.1 \%$ respectively, in Eastern Africa; 33.1\%, 13.4\%, 38\%, 6.5\%, and $4.2 \%$ respectively, in Northern Africa; and 28.6\%, $16.8 \%, 41.8 \%, 6.6 \%$, and $5.9 \%$ respectively, in Southern Africa (Table A1(a)-(f)).

For comparison with other parts of the world, for the United Kingdom's 65.8 million people, the figures are $17.63 \%, 11.49 \%, 39.67 \%, 12.73 \%$ and $18.48 \%$ respectively; for France's 67.85 million people, the figures are $18.36 \%, 11.88 \%$, $36.83 \%, 12.47 \%$ and $20.46 \%$ respectively; for Germany's 80.2 million people, the figures are $12.89 \%, 9.81 \%, 38.58 \%, 15.74 \%$, and $22.99 \%$, respectively; for China's 1.394 billion people, the figures are $17.29 \%, 11.48 \%, 46.81 \%, 12.08 \%$, and $12.34 \%$, respectively; for the European Union's 453 million people, the figures are $15.05 \%, 10.39 \%, 40.54 \%, 13.52 \%$, and $20.5 \%$, respectively; for India's 1.33 billion population, the figures are $26.31 \%, 17.51 \%, 41.56 \%, 7.91 \%$, and $6.72 \%$, respectively; and for the world's 7.684 billion population, the figures are $25.33 \%$, $15.42 \%, 40.67 \%, 9.09 \%$, and 9.49\%, respectively (Compiled from the 2020 World Factbook).

Among individual countries in the world, a very high proportion aged $0-14$ were located in Africa. In 2020, the country with the highest proportion of people under the age of 15 is Niger, with 50.58\%. Other African nations with $45 \%$ or higher were: Uganda, 48.21\%; Malawi, 45.87\%; Angola, 47.83\%; Mali, 47.69\%; Chad, 47.43\%; the Democratic Republic of Congo, 46.38\%; Zambia, 45.74\%; Mozambique, 45.57\%; and Benin, 45.56\% (Table A1(a)-(f)).

A total of 35 countries in Africa had median age of 20 years or younger in 2020, with significant numbers of them in Middle, Western and Eastern Africa. There were 8 out of 9 countries in Middle Africa with a median age of 20 years or less in 2020: Angola, 15.9 years; Chad, 16.1 years; Democratic Republic of Congo, 16.7 years; Cameroon, 18.5 years; Sao Tome \& Principe, 19.3 years; Republic of Congo, 19.5 years; Central African Republic, 20 years; and Equatorial Guinea, 20.3 years (rounded). There were 14 out of 20 countries in Eastern Africa with a median age of 20 years or less; Uganda, 15.7 years; Malawi, 16.8 years; Zambia, 16.9 years; Mozambique, 17 years; Mayotte, 17.3 years (2010); Burundi, 17.7 years; Tanzania, 18.2 years; Somalia, 18.5 years; South Sudan, 18.6 years; Rwanda, 19.7 years; Ethiopia, 19.8 years; Kenya, 20 years; and Eritrea and Madagascar each, 20.3 years (rounded) (Table A3(a)-(f)). There were 12 out of 17 nations in Western Africa with a median age of 20 years or less: Niger, 14.8 years; Mali, 16 years; Benin, 16.4 years; Burkina Faso, 17.9 years; Guinea-Bissau and Liberia each, 18 years; Nigeria, 18.6 years; Guinea and Sierra Leone each, 19.1 years; Senegal, 19.4 years; Togo, 20 years; and Cote d'Ivoire, 20.3 (rounded). There is only one country in Northern Africa with a median age of 20 years or less: Sudan, 18.7 years; Western Sahara, 21.8 years; Egypt, 24.1 years; Libya, 25.8 years; Algeria, 28.9 years; Morocco, 29.1 years; and Tunisia, 32.7 years. Finally, 
there is not a single nation in Southern Africa with a median age of 20 years or less: Namibia, 21.8 years; eSwatini, 23.7 years; Lesotho, 24.7 years; Botswana, 25.7 years; and South Africa, 28 years (Table A3(a)-(f)).

\section{Factors Responsible for Africa's Rapid Population Growth}

There are many interrelated factors that have contributed to the rapid and consistent growth of Africa's population from 1950 to 2020. Many of these interrelated factors are demographic, while others are educational. Combined, these interrelated factors have come to be the engine behind Africa's rapid and massive population growth in the post-World War era. The interrelated factors are as follows: high crude birth rates; high fertility rates; childbirth at a young age; low rates of contraceptive use in most African nations; decline in infant mortality rates; decline in maternal mortality rates; decline in overall death rates; increase in life expectancy; and decline in HIV/AIDS related deaths. These interrelated demographic, social, and economic factors provide a comprehensive explanation for Africa's rapid and massive population growth in the post-World War II era. No thorough explanation can be presented for this phenomenon without these factors presented below.

\subsection{High Crude Birth Rates}

Although the crude birth rates in African nations have been gradually decreasing in recent decades, they are still relatively high compared with other regions of the world and the world average. It is noted that 134 million children are born annually in the world (Baar, 2013: p. 33). A substantial proportion of those births take place in Africa. For example, according to Abate (1978), the average crude birth rate in Africa in 1977 was 45 births per 1000 of the population, and 30 births per 1000 in the world. In Benin, Liberia, Mali, Niger, Togo, Madagascar, Rwanda, and Zambia, it was over 50 births per 1000; 36 births in Egypt; 34 births in Tunisia; 37 births in Equatorial Guinea; and 32 births in Gabon (p. 15). In 2020, the average crude birth rate in Africa was 30.4 births per 1000 of the population: 34.9 births in Middle Africa; 32.6 births in Western Africa; 30.9 births in Eastern Africa; 23.7 births in Northern Africa; and 22.7 births in Southern Africa. The following African nations have rates of 40 births or more: 47.5 births in Niger; 42.7 births in Angola; 42.3 births in Uganda; 42.2 births in Mali; 42.1 births in Benin; 41.7 births in Chad; 41 births in the Democratic Republic of Congo; 40.4 births in Zambia; and 40.1 births in Malawi (Table A3(a)-(c)). For comparison with other world regions or nations, the figures were 9.5 births in the European Union; 11.6 births in China; 18.2 births in India; 12.4 births in the United States; and an average of 18.1 births for the world (Compiled from the 2020 CIA World Factbook).

\subsection{High Total Fertility Rates}

Like the crude birth rates, the total fertility rates (children born per woman) in 
African nations have declined significantly in the past several decades, but they are still relatively high when compared with other regions of the world. According to Kaba (2007), the average total fertility rate in Africa in 2006 was 4.68 children born per woman. In 2020, the average total fertility rate in Africa was 4.3 births per woman. The following countries in Africa had total fertility rates of over 5 births per woman in 2020: 7 in Niger; 5.96 in Angola; 5.77 in the Democratic Republic of Congo; 5.72 in Mali; 5.54 in South Sudan; 5.54 in Uganda; 5.53 in Benin; 5.51 in Somalia; 5.49 in Zambia; 5.4 in Mayotte (2010 estimate); 5.31 in Malawi; 5.28 in Burundi; and 4.97 in Mozambique (rounded) (Table A3(a)). For comparison, in 2020, the world average was 2.42 births per woman; 1.62 in the European Union; 1.6 in China; 2.35 in India; and 1.84 in the United States (Compiled from the 2020 CIA World Factbook).

\subsection{Childbirth at a Young Age}

Another significant factor that has contributed to Africa's rapid population growth is that females have children at a relatively young age. As a result, females tend to have time to have more children, compared with someone who has a first child in their mid to late thirties or early forties. For example, in 2015, the mother's mean age at the time of first birth in the United States was 26.4 years; 30.7 years in Japan; 29.4 years in Germany; 28.5 years in the United Kingdom (2014 est.); and 28.1 years in Canada (2012 est.) (Compiled from the 2020 CIA World Factbook). Among African nations, however, Table A3(a) illustrates that the mother's mean age at the time of first birth was under 20 years in the following nations: 17.9 years in Chad (2014/2015 est.); 18.1 years in Niger (2012 est.); 18.9 years in Malawi (2015/2016 est.); 18.9 years in Mozambique (2011 est.); 18.9 years in Uganda (2011 est.); 19.2 years in Liberia (2013 est.); 19.2 years in Sierra Leone (2013 est.); 19.2 years in Zambia (2013/2014 est.); 19.4 years in Angola (2015/2016 est.); 19.4 years in Burkina Faso (2010 est.); 19.4 years in Sao Tome \& Principe (2008/2009 est.); 19.5 years in Guinea (2018 est.); 19.5 years in Madagascar (2008/2009 est.); 19.7 years in Cameroon (2011est.); 19.8 years in Cote d'Ivoire (2011/2012 est.); 19.8 years in Tanzania (2015/2016 est.); 19.8 years in the Republic of Congo (2011/2012 est.); and 19.8 years in the Democratic Republic of Congo (2013/2014 est.) (Table $\mathrm{A} 3(\mathrm{a}))$.

\section{Low Rates of Contraceptive Use in Most African Nations}

Another important factor that has contributed to the rapid and massive population growth in Africa is that the contraceptive use in most nations across the continent is relatively low, meaning that family planning policies are not as prevalent as in other parts of the world. For example, in 2017, the contraceptive prevalence use in China was 84.5\%; 75.9\% in the United States (2015/2017 est.); $53.5 \%$ in India (2015/2016 est.); $39.8 \%$ in Japan (2015 est.); and $80.3 \%$ in Germany (2011 est.) (Compiled from the 2020 CIA World Factbook). 
However, in Africa, the contraceptive prevalence use is less than $20 \%$ in the following nations: 4\% in South Sudan (2010 est.); 5.7\% in Chad (2014/2015 est.); 8.4\% in Eritrea (2010 est.); 8.7\% in Guinea (2016 est.); 9\% in The Gambia (2013 est.); $11 \%$ in Niger (2018 est.); 12.2\% in Sudan (2014); 12.6\% in Equatorial Guinea (2011 est.); $13.7 \%$ in Angola (2015/2016 est.); $15.2 \%$ in the Central African Republic (2010/2011 est.); 15.5\% in Benin (2017/2018 est.); 15.6\% in Mali (2015 est.); 16\% in Guinea Bissau (2014 est.); 17.8\% in Mauritania (2015 est.); 19\% in Djibouti (2012 est.); 19.4\% in Comoros (2012 est.); and 19.9\% in Togo (2013/2014 est.) (Table A3(a)).

\subsection{Decline in Infant Mortality Rates}

Infant mortality rates in African countries were once very high, but they have been steadily declining, even though they continue to be substantially higher than many regions of the world. These declines in infant mortality rates have contributed to the rapid growth of Africa's population. Infant mortality rates in African nations continue to be higher for males than their female counterparts. For example, the average infant mortality rate in Africa in 1977 was 154 deaths per 1000 live births; 175 deaths in Western Africa; 165 deaths in Middle Africa; 151 deaths in Eastern Africa; 130 deaths in Northern Africa; and 119 deaths in Southern Africa. Some nations with the lowest rates in 1977 were: Cape Verde, 79; Sao Tome \& Principe, 64; Mauritius, 46; Reunion, 47; and Seychelles, 39. Some countries with the highest rates were: Guinea Bissau, 208; Kenya, 119; South Africa, 117; Egypt, 116; Lesotho, 114; Madagascar, 102; and Botswana, 97. The average infant mortality rate in the world in 1977 was 103 deaths per 1000 live births (Abate, 1978: p. 16). In 2006, the average infant mortality rate in Africa was 73.68 deaths per 1000 live births (79.67 for males and 67.50 for females): 35.01 ( 37.37 for males and 32.52 for females) deaths in Northern Africa; 64.31 (67.70 for males and 60.81 for females) deaths in Southern Africa; 70.54 (76.30 for males and 64.61 for females) deaths in Eastern Africa; 86.40 (94.18 for males and 78.39 for females) deaths in Western Africa; and 87.27 (94.22 for males and 80.07 for females) deaths in Middle Africa (Kaba, 2007: pp. 78-80).

In 2020, the average infant mortality rate in Africa was 42.8 deaths per 1000 live births (47.4 deaths for males and 38 deaths for females): 56.7 (61.1 deaths for males and 52.1 deaths for females) deaths in Middle Africa; 48.7 (53.7 deaths for males and 43.5 deaths for females) deaths in Western Africa; 40.5 (45.7 deaths for males and 34.6 deaths for males) deaths in Eastern Africa; 34.1 (37.2 deaths for males and 30.9 deaths for females) deaths in Southern Africa; and 20.6 (25.9 deaths for males and 21.1 deaths for females) deaths in Northern Africa. The nations in Africa with infant mortality rates of 50 deaths or more are as follows: 89.5 (97.8 deaths for males and 54 deaths for females) deaths in Somalia; 80.6 (87.7 deaths for males and 73.2 deaths for females) in the Central African Republic; 69.9 (76 deaths for males and 63.5 deaths for females) deaths in South Sudan; 68.6 (74.5 deaths for males and 62.5 deaths for females) deaths in Chad; 
67.7 (72 deaths for males and 63.3 deaths for females) deaths in Niger; 64.7 (66.8 deaths for males and 62.6 deaths for females) deaths in Mozambique; 64.5 (70.3 deaths for males and 58.4 deaths for females) deaths in the Democratic Republic of Congo;64 (69.6 deaths for males and 58.3 deaths for females) deaths in Mali; 63.6 (71.6 deaths for males and 55.4 deaths for females) deaths in Sierra Leone; 62.3 (67.8 deaths for males and 56.8 deaths for females) deaths in Angola; 59.8 (65.4 deaths for males and 54 deaths for females) deaths in Nigeria; 59.7 (60.8 deaths for males and 58.6 deaths for females) deaths in Equatorial Guinea; 59.1 (66.7 deaths for males and 51.2 deaths for females) deaths in Cote d'Ivoire; 58.7 (63.9 deaths for males and 53.3 deaths for females) deaths in Benin; 54.9 (60.1 deaths for males and 49.6 deaths for females) deaths in The Gambia; 54.75 (60.23 deaths for males and 49.09 deaths for females) deaths in Mayotte (2010 estimate): 52.4 (57.3 deaths for males and 47.3 deaths for females) deaths in Guinea; 52 (56.4 deaths for males and 47.5 deaths for females) deaths in Burkina Faso; 51.9 (57.9 deaths for males and 45.7 deaths for females) deaths in Guinea-Bissau; 51.5 (56.5 deaths for males and 46.3 deaths for females) deaths in Cameroon; and 50.7 (55.3 deaths for males and 45.9 deaths for females) deaths in the Republic of Congo. For comparison, in 2020, the figures were: 30.8 (32.8 deaths for males and 28.6 deaths for females) deaths in the World; 3.7 (4 deaths for males and 3.3 deaths for females) deaths in the European Union; 5.3 (5.7 deaths for males and 4.9 deaths or females) deaths in the United States; 11.4 (11.9 deaths for males and 10.9 deaths for females) deaths in China; and 35.4 (34.4 deaths for males and 36.5 deaths for females) deaths in India (Compiled from the 2020 CIA World Factbook).

\subsection{Decline in Maternal Mortality Rates}

Another important factor that has contributed to the rapid and massive population growth in Africa is the gradual decline in maternal mortality rates in African countries. For example, according to the United Nations Children's Fund (UNICEF), in 2000, the average maternal mortality rate in the world was 342 deaths per 100,000 of the population. In 2010, that figure declined to 248 deaths, and in 2017, it declined again to 211 deaths: 12, 14, and 18 respectively, in North America; 8, 6, and 5 respectively, in Western Europe; 27, 17, and 13 respectively, in Europe and Central Asia; 114, 86, and 69 respectively, in East Asia and the Pacific; 395, 235, and 163 respectively, in South Asia; 95, 63, and 57 respectively, in the Middle East and North Africa; and 870, 626, and 533 respectively, in sub-Saharan Africa ("Maternal Mortality Ratio (MMR) Trends by Region", 2019).

Tables A3(a)-(f) present maternal mortality rates in African countries for the year 2017. In 2017, the average maternal mortality rate for 52 nations in Africa was 436.4 deaths per 100,000 of the population: 581.9 in Western Africa; 474.8 in Eastern Africa; 420.1 in Eastern Africa; 287.8 in Southern Africa; and 104.8 deaths in Northern Africa. The African nations with maternal mortality rates of 600 deaths or more in 2017 are as follows: 1150 in South Sudan; 1140 in Chad; 
1120 in Sierra Leone; 917 in Nigeria; 829 each in the Central African Republic and Somalia; 766 in Mauritania; 667 in Guinea Bissau; 661 in Liberia; and 617 in Cote d'Ivoire (Tables A3(a)-(f)).

\subsection{Decline in the Overall Death Rates}

The overall death rates in African countries have declined substantially in the past several decades. This phenomenon has directly contributed to the rapid growth in Africa's total population. For example, the death rate in Africa in 1977 was 19 deaths per 1000 of the population: 23 deaths in Western Africa; 22 deaths in Middle Africa; 19 deaths in Eastern Africa; 16 deaths in Southern Africa; and 14 deaths in Northern Africa. The world average in 1977 was 12 deaths per 1000 (Abate, 1978: p. 15). In 2005, the average death rate in Africa was 14.76 deaths per 1000 of the population: 5.54 deaths in Northern Africa; 14.47 deaths in Western Africa; 14.64 deaths in Eastern Africa; 15.29 deaths in Middle Africa; and 23.87 deaths in Southern Africa (Kaba, 2009b: p. 339). By 2020, the average death rate for Africa as a whole had improved to the point that it was higher than those of the European Union, China and the United States. For example, in 2020, the average death rate in Africa was 7.8 deaths per 1000 of the population: 10.3 deaths in Southern Africa; 8.4 deaths in Middle Africa; 7.9 deaths in Western Africa; 7.6 deaths in Eastern Africa; and 5.6 deaths in Northern Africa. For comparison, in 2020 , the average death rate in the world was 7.7 deaths per 1000; 10.7 deaths in the European Union; 8.3 deaths in the United States; 8.2 deaths in China; and 7.3 deaths in India (Compiled from the 2020 CIA World Factbook).

\subsection{Increase in Life Expectancy in African Nations}

An important contributing factor for the massive population growth in Africa is the increase in the average life expectancy of people. For example, in 1977, the average life expectancy at birth in Africa was 46 years: 53 years in Northern Africa; 51 years in Southern Africa; 45 years in Eastern Africa; 42 years in Middle Africa; and 42 years in Western Africa. The average for the world was 59 years (Abate, 1978: p. 16). According to Clapham (2006), in 2002, the average life expectancy at birth in sub-Saharan Africa was 46 years (p. 96). In 2005, the average life expectancy at birth in Africa was 52.62 years (51.46 years for males and 53.83 for females). The world average in 2005 was 64.33 years ( 62.73 years for males and 66.04 years for females) (Kaba, 2009b: pp. 338-339). In 2020, the average life expectancy at birth in Africa was 65 years. The nations in Africa with life expectancy at birth of 67 years and higher are as follows: 80 (77.1 years for males and 83.1 years for females) years in Saint Helena; 77.5 (76.1 years for males and 79.1 years for females) years in Algeria; 76.7 (74.4 years for males and 79.1 years for females) years in Libya; 76.5 (73 years for males and 80.1 years for females) years in Mauritius; 76.3 (74.6 years for males and 78.1 years for females) years in Tunisia; 75.6 (71.1 years for males and 80.2 years for females) years in Seychelles; 74.18 (2006 est., 70.78 years for males and 77.75 years for 
females) years in Reunion; 73.7 (72.3 years for males and 75.3 years for females) years in Egypt; 73.3 (71.6 years for males and 75.1 years for females) years in Morocco; 73.2 (70.8 years for males and 75.6 years for females) years in Cabo Verde; 69 (67.3 years for males and 70.8 years for females) years in Gabon; 69 (67.3 years for males and 70.6 years for females) years in Kenya; 68.2 (65.6 years for males and 70.8 years for females) years in Ghana; 68.2 (66 years for males and 70.5 years for females) years in Uganda; 67.5 (65.5 years for males and 69.7 years for females) years in Ethiopia; and 67.3 (65.7 years for males and 68.9 years for females) years in Madagascar (Tables A2(a)-(f)).

\subsection{Decline in HIV/AIDS Related Deaths in Sub-Saharan African Nations}

There is a substantial decline in the HIV/AIDS related deaths in sub-Sharan African nations from 2005 to 2019, which have contributed to the rapid increase in Africa's population. For example, in 2005, of the 2,800,000 HIV/AIDS related deaths in the world, 2,000,000 (71.4\%) were in sub-Saran African nations, and 37,000 (1.3\%) were in North Africa and the Middle East ("2006 Report on the global AIDS epidemic", 2006: p. 13). Of the 690,000 HIV/AIDS related deaths in the world in 2019, 440,000 (63.8\%) were in sub-Saran African nations, and 92,000 (13.3\%) were in North Africa and the Middle East ("Fact Sheet: Global HIV Statistics", 2020: p. 6; also see Kaba, 2014: p. 63). These HIV/AIDS related deaths in sub-Saharan Africa show a decline of 1.56 million people from 2005 to 2019. According to Clapham (2006), the life expectancy in sub-Saharan Africa fell by six years from 1995 to 2003 , “... a drop to be explained almost entirely by the impact of HIV/AIDS” (p. 96).

\section{Implications of this Phenomenon}

There are a number of interrelated implications as a result of the massive population growth in Africa from 1950 to 2020. Some might argue that some of these implications may have resulted in at least part of the massive population growth during this post-World War II period. One implication, as a result of the growth in Africa's population is the gradual increase in Africa's Gross Domestic Product (GDP), GDP per capita, and the rise in the numbers of billionaires and millionaires in Africa, especially in the past two decades. When a population becomes so large, with over 1 billion people, the potential for individuals to accumulate wealth as entrepreneurs or businessmen and businesswomen becomes high because of a large domestic market. For example, the total Gross Domestic Product (GDP) of all of Africa in 2005 was $\$ 2.366$ trillion, 3.9\% of the Gross World Product (GWP), purchasing power parity (PPP) of $\$ 60.71$ trillion: $\$ 909.9$ billion (38.5\% of Africa's total) for Northern Africa; $\$ 575.45$ billion (24.33\%) for Southern Africa; $\$ 377.84$ billion (16\%) for Western Africa; $\$ 315.32$ billion (13.33\%) for Eastern Africa; and $\$ 151.66$ billion (6.41\%) for Middle Africa. In 2005, the GDP per capita was $\$ 7600$ for Middle Africa: $\$ 7400$ for Southern Africa; $\$ 6183$ for 
Northern Africa; \$2421 for Eastern Africa; and \$1818 for Western Africa (Kaba, 2007: pp. 78-80).

In 2017, Africa's total GDP (PPP) increased to $\$ 5.519$ trillion (4.32\% of the GWP of $\$ 127.8$ trillion); $\$ 1.703$ trillion (30.9\% of Africa's total) for Northern Africa; $\$ 1.608$ (29.1\%) trillion for Western Africa; $\$ 905.72$ (16.4\%) billion for Eastern Africa; $\$ 851.1$ (15.4\%) billion for Southern Africa; and $\$ 450.5$ (8.2\%) billion for Middle Africa. In 2017, the GDP per capita in Africa was $\$ 4433$ ( $\$ 5.519$ trillion divided by 1.245 billion people in 2017); $\$ 13,600$ for Southern Africa; \$7315 for Northern Africa; \$4302 for Western Africa; \$2556 for Middle Africa; and $\$ 2268$ for Eastern Africa (Tables A4(a)-(f)).

According to The Wealth Report (2020), in 2014, there were 30 billionaires in Africa, with at least $\$ 1$ billion. In 2019, that figure dropped to 22. In 2014, there were 242,765 Africans in Africa with at least $\$ 1$ million. In 2019, that figure increased to 302,360, a 25\% increase ("The Wealth Report", 2020: pp. 104-105; also see Kaba, 2015: p. 26; Kaba, 2017). Forbes Magazine reports that: “Africa's billionaires are as a group richer than a year ago. Altogether, the continent's 20 billionaires are worth a combined $\$ 73.4$ billion, up from $\$ 68.7$ billion a year ago" (“Africa's Richest 2020", 2020, February 6).

Another implication of Africa's massive population growth is the rise in political influence in the international community of Africa or African countries acting as a block at global institutions such as the United Nations, World Trade Organization (WTO) or the International Monetary Fund (IMF). African countries represent a substantial proportion of these world bodies. As a result, world powers such as the United States, China and Russia compete regularly for support from African countries on important world issues (Brooke, 2007; Dreher et al., 2009; Flores-Macías \& Kreps, 2013; Hendricks, 2017; Hwang et al., 2015). According to Brookes (2007):

"One of the places China is seeking political influence at the expense of others is Africa. Think about it: With over 50 nations, the countries of Africa represent more than one-quarter of the United Nations General Assembly-a significant voting bloc. Friendly relations with African nations can bring favorable results for Chinese efforts at the United Nations or U.N. agencies such as the World Trade Organization. They can even reduce the number of states that diplomatically recognize Taiwan: There are five countries in Africa that still recognize Taiwan. For example, in recent years, African states have been pivotal in preventing Taiwan from joining the World Health Organization and in tabling a condemnation of Chinese human rights practices at the U.N.'s Commission on Human Rights" (pp. 2-3).

Data in the study by Flores-Macías and Kreps (2013) on relations between African nations and China show "that growing commercial ties foster foreign policy convergence”. In addition, the study finds: “...that as China's trade volume with Africa... has grown, so generally has the convergence of foreign poli- 
cies of [Africa and] China. ... the more salient the trade relationship with China has become for African economies, the more frequently these countries have voted with China on country-specific human rights votes in the UN General Assembly" (p. 363).

Another important implication that has resulted from the massive population growth in Africa, which is linked to the two other implications cited above is increase in higher education attainment (enrollment and degree attainment) in Africa. The world has observed that just having the ability to enroll in tertiary or higher education can result in many opportunities for individuals. The American billionaires Mark Zuckerberg, founder of Facebook and the founder of CNN television Ted Turner attended college (Harvard University and Brown University, respectively), but never graduated. Yet, their experiences in college contributed to their success. In addition, while the gross enrollment ratio in tertiary education in Africa is significantly lower than other regions of the world, the continent has made substantial progress in the past several decades.

Before examining the tertiary enrollment and degree attainment figures in Africa in the past several decades, let us first examine the progress that has been made in terms of school life expectancy, literacy rates, and education expenditures as percent of Gross Domestic Product (GDP). Tables A4(a)-(f) present data on literacy rates (those aged 15 and over who can read and write), school life expectancy, and education expenditures as percent of GDP in Africa. The literacy rates and the figures for school life expectancy are higher for males than their female counterparts. A 2002 UNESCO statistics showed that, in 1970, the illiteracy rate (cannot read and write) in Africa was $72.4 \%$, and the world average was 36.6 percent. In 2000 , those figures improved to $40.2 \%$ and $20.3 \%$, respectively (Kaba, 2007: pp. 78-80).

Table A4(a) presents literacy rates for African nations, which are from 2015 to 2018 . The following nations have rates of $80 \%$ or more: $95.9 \%$ (95.4\% for males and $96.4 \%$ for females) in the Seychelles (2018 est.); $95.3 \%$ (97.4\% for males and 93\% for females) in Equatorial Guinea (2015 est.); 92.8\% (96.2\% for males and 89.5\% for females) in Sao Tome \& Principe (2018 est.); $91.5 \%$ (91.6\% for males and 91.4\% for females) in Namibia (2018 est.); 91.3\% (91.3\% for males and $93.4 \%$ for females) in Mauritius (2018 est.); $91 \%$ (96.7\% for males and $85.6 \%$ for females) in Libya (2015 est.); $88.5 \%$ (88\% for males and $88.9 \%$ for females) in Botswana (2015 est.); $88.4 \%$ ( $88.3 \%$ for males and $88.5 \%$ for females) in eSwatini (2015 est.); $87 \%$ ( $87.7 \%$ for males $86.5 \%$ for females) in South Africa (2017 est.); $86.8 \%$ (91.7\% for males and $82 \%$ for females) in Cabo Verde (2015 est.); $86.7 \%$ (90.6\% for males and $83.1 \%$ for females) in Zambia (2018 est.); 86.5\% (88.5\% for males and $84.6 \%$ for females) in Zimbabwe (2015 est.); 84.7\% (85.9\% for males and $83.4 \%$ for females) in Gabon (2018 est.); $81.8 \%$ (89.6\% for males and $74.2 \%$ for females) in Tunisia (2015 est.); 81.5\% (85\% for males and 78.2\% for females) in Kenya (2018 est.); 81.4\% (87.4\% for males and 75.3\% for males) in Algeria (2018 est.); and $80.3 \%$ (86.1\% for males and $74.6 \%$ for females) in the Republic 
of Congo (2018 est.) (Table A4(a)).

The school life expectancy data (from 2011 to 2018) show the following nations have rates of 12 years or more: 16 ( 15 years for males and 16 years for females) years in the Seychelles (2016 est.); 15 (14 years for males and 16 years for females) years in Mauritius (2017 est.); 15 (14 years for males and 16 years for females) years in Tunisia (2016 est.); 14 (14 years for males and 15 years for females) years in Algeria (2011 est.); 14 (13 years for males and 14 years for females) years in South Africa (2016 est.); 13 (14 years for males and 11 years for females) years in Benin (2016 est.); 13 (13 years for males and 13 years for females) years in Botswana (2013 est.); 13 (14 years for males and 12 years for females) years in Cameroon (2016 est.); 13 (13 years for males and 13 years for females) years in Egypt (2017 est.); 13 (14 years for males and 13 years for females) years in Morocco (2016 est.); 13 (14 years for males and 11 years for females) years in Togo (2017 est.); 12 (12 years for males and 13 years for females) years in Sao Tome \& Principe (2015 est.); 12 (12 years for males and 12 years for females) years in Cabo Verde (2017 est.); and 12 (12 years for males and 11 years for females) years in Ghana (2017 est.) (Table A4(a)).

The education expenditure as percent of GDP, ranging from the years 2009 to 2018, show the following African nations with 5\% and higher: 9.6\% in Botswana (2009 est.); $7.1 \%$ in eSwatini (2014 est.); 6.6\% in Tunisia (2015 est.); 6.5\% in Mozambique (2013 est.); 6.4\% in Lesotho (2018 est.); 6.2\% in South Africa (2018 est.); 6.1\% in Zimbabwe (2014 est.); 5.3\% in Morocco (2009 est.); 5.2\% in Kenya (2017 est); 5.2\% in Cabo Verde (2017 est); 5.1\% in Cote d'Ivoire (2017 est); and $5 \%$ in Togo (2016 est.) (Table A4(a)).

Turning now to tertiary education, according to the United Nations Educational, Scientific and Cultural Organisation (UNESCO), tertiary education enrollment experienced a faster growth in sub-Saharan Africa than other regions in the world. For example, in 1970, the gross enrollment ratio in tertiary education in sub-Saharan Africa was less than 1\%. By 2008, that figure increased to 6 percent, but an average of $26 \%$ for the world. However, in 1970, there were fewer than 200,000 students enrolled in tertiary education in sub-Saharan Africa. In 2008, that figure increased to over 4.5 million students, over 20 -fold increase. The gross enrollment ratio (GER) in tertiary education in sub-Saharan Africa increased at an average rate of $8.6 \%$ every year from 1970 to 2008 , but $4.6 \%$ during that period for the world average. This was an important development because that rate of $8.6 \%$ exceeded the growth rate of "the relevant age group across" sub-Saharan Africa. By 2009, the GER in tertiary education exceeds the average for sub-Saharan African nations: 9\% in Cameroon; 14.9\% in Cabo Verde; $8.4 \%$ in Côte d'Ivoire; 6.2\% in Ghana; $9.2 \%$ in Guinea; $25.9 \%$ in Mauritius; $8.9 \%$ in Namibia; and $8 \%$ in Senegal. However, for a number of African nations, the GER continues to be relatively low in the following nations: $3.4 \%$ in Burkina Faso; 2.7\% in Burundi; 2.5\% in the Central African Republic; 2\% in Chad; $2 \%$ in Eritrea; 3.6\% in Ethiopia; 3.6\% in Madagascar; 0.5\% in Malawi; 
1.4\% in Niger; and 3.7\% in Uganda ("Trends in Tertiary Education: Sub-Saharan Africa", 2010: p. 1).

A significant number of African college students are enrolled at institutions outside of their countries. In 2008, there were 223,000 sub-Saharan African students enrolled in higher education institutions outside of their countries, representing 7.5\% of the 3 million students enrolled outside of their countries. It is also noted that in 2008: “... nearly two-thirds (65.1\%) of mobile students from the region [sub-Saharan Africa] studied in North America and Western Europe.... Top destinations were: Australia (3.1\%), Canada (2.3\%), France (20.6\%), Germany (3.8\%), Italy (1.5\%), Morocco (2.0\%), Portugal (5.2\%), the United States (14.2\%) and the United Kingdom (12.7\%)" ("Trends in Tertiary Education: Sub-Saharan Africa", 2010: pp. 4-5). According to the World Bank, in 2018, the "school enrollment, tertiary (\% gross)" was 9\% in sub-Saharan Africa. It was $5 \%$ or more in the following African nations: $41 \%$ in Mauritius (2017); $25 \%$ in Botswana (2017); 24\% in Cabo Verde (2018); $23 \%$ in Namibia (2017); $22 \%$ in South Africa (2017); 17\% in Seychelles (2018); 17\% in Sudan (2015); 16\% in Ghana (2018); $15 \%$ in Togo (2018); 13\% in Cameroon (2017); 13\% in the Republic of Congo (2017); 13\% in Sao Tome \& Principe (2015); 13\% in Senegal (2018); $12 \%$ in Benin (2017): 12\% in Guinea (2014); 12\% in Liberia (2012); 11\% in Kenya (2017); 10\% in Lesotho (2018); 10\% in Nigeria (2011); 9\% in Angola (2016); 10\% in Zimbabwe (2015); 9\% in Comoros (2014); 9\% in Cote d'Ivoire (2017); 8\% in Ethiopia (2014); 8\% in Gabon (2003); 7\% in Burkina Faso (2018); 7\% in the Democratic Republic of Congo (2016); 7\% in eSwatni (2013); 7\% in Mozambique (2018); 7\% in Rwanda (2018); 6\% in Burundi (2017); 5\% in Madagascar (2018); 5\% in Mali (2017); 5\% in Mauritania (2017); and 5\% in Uganda (2014) ("School Enrollment, Tertiary (\% Gross)-Sub-Saharan Africa", 2020).

According to the World Bank, the cumulative percent of women aged 25 and over in sub-Saharan African nations who had completed "short-cycle tertiary" education with 5\% or more are as follows: $16.9 \%$ in Mauritius (2018);13.8\% in Nigeria (2006); 10.5\% in Cabo Verde (2015); 7.7\% in Zimbabwe (2017); 7.4\% in South Africa (2015); 6\% in Seychelles (2002); 5.5\% in Uganda (2012); and 5\% in the Republic of Congo (2016) ("Educational Attainment, at Least Completed Short-Cycle Tertiary, Population 25+, Female", 2020). According to the World Bank, the cumulative percent of men aged 25 and over in sub-Saharan African nations who had completed "short-cycle tertiary" education with $5 \%$ or more are as follows: $20.8 \%$ in Nigeria (2006); $13.6 \%$ in the Democratic Republic of Congo (2016); 11.4\% in Zimbabwe (2017); $11.1 \%$ in Uganda (2012); $10.8 \%$ in Mauritius (2018); 9.4\% in the Seychelles (2002); 9\% in Cabo Verde (2015); 8.3\% in South Africa (2015); 7.1\% in Cote d'Ivoire (2014); 6.9\% in Senegal (2017); 5.2\% in Guinea (2010); 5\% in Rwanda (2018); and 4.7\% in Ghana (rounded, 2010) ("Educational Attainment, at Least Completed Short-Cycle Tertiary, Population 25+ Male", 2020). 


\section{Recommendations}

African people and their governments need to protect the achievements they have made with their population growth, wealth accumulation, educational attainment and rising influence in international relations and politics. Their massive population growth in the post-World War II era is the primary reason for these achievements. In order to maintain and build on these important achievements, African people and their governments need to consider a number of recommendations.

One recommendation is for African nations to seriously consider making the African Union a fully-fledged state, with central powers. A fully-fledged federal African Union, with a population of over 1.3 billion people will be in a stronger position to protect the interests and well-being of all member states at home and abroad. Many African nations have signed long-term contracts in trade with foreign nations that put these African nations at a disadvantage. Only a federal African Union can be in the powerful position to change the terms of those bad trade agreements (Kaba, 2005, 2009a, 2014). The continent of Africa is endowed with strategic natural resource that nations all over the world need for their economic development. However, individual African nations are too small or too weak to negotiate with powerful countries to get a fair price for their resources. For example, Kaba points out that: "The natural resources of Nigeria... include: natural gas, petroleum, tin, iron ore, coal, limestone, niobium, lead, zinc and arable land; in Liberia: iron ore, timber, diamonds, gold and hydropower; in Sierra Leone: diamonds, titanium ore, bauxite, iron ore, gold, chromite; in Cote d'Ivoire: petroleum, natural gas, diamonds, manganese, iron ore, cobalt, bauxite, copper, gold, nickel, tantalum, silica sand, clay, cocoa beans, coffee, palm oil, hydropower; and in Niger: uranium, coal, iron ore, tin, phosphates, gold, molybdenum, gypsum, salt, [and] petroleum" (p. 77).

Another recommendation is that African nations must maintain the relatively good health that they now enjoy. Although as Tables A4(a)-(f) illustrate, the government health expenditures in African nations are not as large in total dollars as those in Europe, North America and some Asian nations, they are significant enough to have resulted in the relatively good health that Africans enjoy today. An additional reason also is that the tens of billions of dollars in remittances being sent to Africa by family members from the diaspora have been used by recipients for medicine and education. For example, in 2016, $\$ 39$ billion were sent to sub-Saharan Africa as remittances; $\$ 42$ billion in 2017; $\$ 48$ billion in 2018; and $\$ 48$ billion in 2019 ("Table 1.2 Estimates and Projections of Remittance Flows", 2020: p. 8). That is a total of $\$ 177$ billion for those four years.

One important factor for the relatively good health of Africans in recent years is that they have low proportions of obese individuals. Obesity causes many serious problems for a society or nation. For example, one reason why COVID-19 cases are not as widespread in most African countries as they are in the United States is obesity. In 2016, the adult obesity prevalence rate was $36.2 \%$ in the 
United States. However, as Table A3 illustrates, in 2016, there were 28 (51.9\%) out of 54 African nations with obesity proportions of $4.5 \%$ to $8.9 \%$; and 12 (22.2\%) nations from $9 \%$ to 12.7 percent. Notice that the nations in Africa with very serious cases of COVID-19 are South Africa and several in Northern Africa. Table A3(a) shows that the obesity figures for South Africa was $28.3 \% ; 32 \%$ in Egypt; $26.1 \%$ in Morocco; $27.4 \%$ in Algeria; and 26.9\% in Tunisia (also see Kaba \& Nkweti-Kaba, 2020). To maintain these relatively low obesity figures, African nations need to carefully monitor their caloric consumption, which is a primary factor for the obesity epidemic in the United States. This is especially as African nations continue to get wealthier. For example, in 1961, the average calorie consumption in the United States was 2880 calories and 1993 calories in Africa. In 2013, that figure increased to 3682 calories in the United States and 2624 calories in Africa ("Daily Supply of Calories, 1961-2013", 2020). A country can become wealthy and still avoid having high proportions of its people to be obese. For example, Japan and South Korea have obesity proportions of $4.3 \%$ and $4.7 \%$ respectively (Kaba \& Nkweti-Kaba, 2020: p. 136). The average caloric intake in Japan in 2013 was 2726 calories and 3334 calories in South Korea ("Daily Supply of Calories, 1961-2013", 2020). African nations must continue consuming organic foods instead of consuming large quantities of food from fast food restaurants such as McDonald's and Kentucky Fried Chicken (KFC), which are increasing in numbers on the continent. For example, Jargon (2010) points out that: "By 2014, the Louisville, Ky., restaurant-holding company expects to double its number of KFC outlets in Africa to 1200. In the next four years, it aims to more than double its revenue on the continent to $\$ 2$ billion". Raduzzi and Massey (2019) point out that "Several fast food restaurants have opened in Morocco, including Subway, Dairy Queen, KFC, Dunkin Donuts, McDonald's, Burger King and Pizza Hut since the early 90's". The authors add that although the first McDonald's restaurant in Africa was opened in Morocco in 1992, “... there are McDonald's restaurants in three other countries in Africa: Egypt, South Africa, and Tunisia" (p. 21), nations with relatively higher obesity percentages in Africa

This brings us to a final recommendation, which is related to the ones presented above: the current African Union or a fully-fledged African Union must take over the healthcare of all member states and establish a universal healthcare for all Africans on the continent. This will take a lot of financial burden off the shoulders of individual member states and allow them to focus on other important priorities. The African Union is in the position and has the resources to strategically build hospitals or medical centers across the continent. The African Union would also attach hospitals or medical centers to a high number of established universities across the continent. Finally, the African Union would strategically distribute medical personnel, including those recruited from the diaspora at these newly established hospitals and medical centers across the continent (Kaba, 2006: pp. 55-63; 2009a: pp. 104-110; 2014: pp. 65-67).

Giving a fully-fledged African Union the responsibility to conduct trade and 
provide universal healthcare for the citizens of member countries will have the potential to speed up the development of the continent. Leaders within member countries will be in the position to redirect or reallocate resources to other important sectors of their states since they no longer will have the responsibility to provide healthcare to their citizens or residents. These leaders will also save substantial amount of time because the African Union will be responsible to negotiate international trade contracts on behalf of all member countries.

\section{Conclusion}

This study began by presenting an overview of the massive increase in Africa's population, relative to other parts of the world, rapidly growing from 228.7 million in 1950 to over 1.341 billion in 2020 . The study discussed the many negative challenges that come with such a massive increase in Africa's population during this period. Some of these challenges discussed include producing sufficient food for the masses, environmental degradation, increased scarcity of fresh water, emigration of millions of people out of the continent, and providing adequate healthcare and education to the masses.

The study goes on to present data on the demographic breakdowns of Africa and its five regions. Of the 1.341 billion people on the continent in 2020, two regions have populations of over 400 million: 431 million in Eastern Africa and 404 million in Western Africa. The continent's population is growing at $2.5 \%$ annually. There are four countries already with 100 million people or more by 2020: 214 million in Nigeria; 108.1 million in Ethiopia; 104.1 million in Egypt; and 101.8 million in the Democratic Republic of Congo. The youngest people in the world are now found in Africa, with Middle Africa and Western Africa having the highest proportions of people under the age of $15: 45.6 \%$ and $42 \%$, respectively.

Table A4(a) shows that despite Africa's rapid population growth, the geographic size of the continent, at 11.635 million square miles, is so massive that there is plenty of space for hundreds of millions more of people in the decades to come. According to Table A4(a), the proportion of people residing in urban areas continues to be relatively low compared with other parts of the world. For example, in 2020, the proportion of the urban population in the United States was $82.7 \%$; $91.8 \%$ in Japan; $81 \%$ in France; and $83.9 \%$ in the United Kingdom (Compiled from the 2020 CIA World Factbook). In Africa, the four nations with 100 million people or more have the following urbanization proportions in 2020: $21.7 \%$, with an urbanization rate of $4.63 \%$ (from 2015-2020) in Ethiopia; $42.8 \%$ and $1.86 \%$, respectively, in Egypt; $45.6 \%$ and $4.53 \%$, respectively, in the Democratic Republic of Congo; and 52\% and $4.23 \%$, respectively, in Nigeria (Table A4(a)).

Some factors cited to have contributed to Africa's rapid population growth in the post-World War II era include: high birth rates; high fertility rates; childbirth at a young age; low rates of contraceptive use; decline in infant mortality 
rates; decline in overall deaths rates; decline in maternal mortality rates; increase in life expectancy; and decline in HIV/AIDS related deaths. The study cited a number of positive implications for this phenomenon, including increase in GDP and GDP per Capita in Africa; increase in the numbers of billionaires and millionaires in Africa; increase in political influence of Africa in the international community; and increase in the number of educated Africans, including those enrolled in college and college graduates. Finally, the study recommends that member states of the African Union make it a fully-fledged federal union in order for it to represent the interests of all member states in the international community, and also for it to implement a universal healthcare system within the entire content.

\section{Conflicts of Interest}

The author declares no conflicts of interest regarding the publication of this paper.

\section{References}

(2015). The 2015 Revision of the UN's World Population Projections. Population and Development Review, 41, 557-561. https://doi.org/10.1111/j.1728-4457.2015.00082.x

(2016). John, C. Caldwell on Major Questions in African Demographic History. Population and Development Review, 42, 343-358. https://onlinelibrary.wiley.com/doi/abs/10.1111/j.1728-4457.2016.00135.x https://doi.org/10.1111/j.1728-4457.2016.00135.x

(2020). Africa's Richest 2020: Steady State with Some Volatility on the Margins. Forbes Magazine, February 6. https://www.forbesafrica.com/cover-story/2020/02/06/africas-richest-2020-steady-state -with-some-volatility-on-the-margins

(2020). Daily Supply of Calories, 1961-2013. Our World in Data. https://ourworldindata.org/food-supply\#caloric-energy-supply

Abate, Y. (1978). African Population Growth and Politics. Issue: A Journal of Opinion, 8, 14-19. https://doi.org/10.2307/1166318

Arku, G. (2009). Rapidly Growing African Cities Need to Adopt Smart Growth Policies to Solve Urban Development Concerns. Urban Forum, 20, 253-270. https://doi.org/10.1007/s12132-009-9047-z

Ashton, P. J. (2002). Avoiding Conflicts over Africa's Water Resources. Ambio, 31, 236-242. https://doi.org/10.1579/0044-7447-31.3.236

Baar, W. (2013). Population Growth and a Multicultural World. Dialogue \& Alliance, 27, 33-44. https://doi.org/10.17857/hw.2013.12.44.1

Badenhorst, L. T. (1951). Population Distribution and Growth in Africa. Population Studies, 5, 23-34. https://doi.org/10.1080/00324728.1951.10416671

Bremner, J. (2012). Population and Food Security: Africa's Challenge. Population Reference Bureau. https://assets.prb.org/pdf12/population-food-security-africa.pdf

Brookes, P. (2007). Into Africa: China's Grab for Influence and Oil. The Heritage Foundation.

https://www.heritage.org/africa/report/africa-chinas-grab-influence-and-oil\#: :text=Pete r\%20researches\%20and\%20develops\%20Heritage's,mass\%20destruction $\% 20$ and $\% 20$ coun 
ter\%20proliferation.\&text=Amid\%20festering\%20concerns\%20about\%20China's,expandi ng\%20its\%20influence\%20in\%20Africa

Casterline, J. B. (2017). Prospects for Fertility Decline in Africa. Population and Development Review, 43, 3-18. https://doi.org/10.1111/padr.12055

Clapham, C. (2006). The Political Economy of African Population Change, 1950-2050. Population and Development Review, 32, 96-114. https://doi.org/10.1111/j.1728-4457.2006.tb00004.x

Dreher, A., Sturm, J.-E., \& Vreeland, J. R. (2009). Global Horse Trading: IMF Loans for Votes in the United Nations Security Council. European Economic Review, 53, 742-757. https://doi.org/10.1016/j.euroecorev.2009.03.002

Ewugi, M. S., \& Yakubu, I. (2012). Malthusian Population Theory and the Nigerian Economy: A Political Economy Approach. International Journal of Human Resource Studies, 2, 197-206. https://doi.org/10.5296/ijhrs.v2i4.2867

Ezeh, A. C., Bongaarts, J., \& Mberu, B. (2012). Global Population Trends and Policy Options. The Lancet, 380, 142-148. https://doi.org/10.1016/S0140-6736(12)60696-5

Flores-Macías, G. A., \& Kreps, S. E. (2013). The Foreign Policy Consequences of Trade: China's Commercial Relations with Africa and Latin America, 1992-2006. The Journal of Politics, 75, 357-371. https://doi.org/10.1017/S0022381613000066

Hakim, C. (2003). New Approach to Explaining Fertility Patterns: Preference Theory. Population and Development Review, 29, 349-374. https://doi.org/10.1111/j.1728-4457.2003.00349.x

Hendricks, C. (2017). Progress and Challenges in Implementing the Women Peace and Security in the African Union's Peace and Security Architecture. Africa Development, 42, 73-98.

Hwang, W., Sanford, A. G., \& Lee, J. (2015). Does Membership on the UN Security Council Influence Voting in the UN General Assembly? International Interactions, 41, 256-278. https://doi.org/10.1080/03050629.2015.982114

Iliffe, J. (1989). Review: The Origins of African Population Growth Reviewed Work(s): African Population and Capitalism: Historical Perspectives. The Journal of African History, 30, 165-169. https://doi.org/10.1017/S0021853700030942

Jargon, J. (2010). KFC Savors Potential in Africa. Wall Street Journal. http://volaray.com/web/wp-content/uploads/2010/12/KFC-sees-potential-in-Africa.pdf

Kaba, A. J. (2005). Africa, America and UN Security Council Reform: The U.S. Must Lead the Movement to Award the African Union a Permanent Seat on the Security Council. African Renaissance, 2, 39-47.

Kaba, A. J. (2006). Population Increase, Environment, Food Access and Development in Africa: The Role of the African Union. Journal of African Policy Studies, 12, 42-68.

Kaba, A. J. (2007). The Two West Africans: The Two Historical Phases of the West African Brain Drain. Journal of Pan African Studies, 1, 77-92.

Kaba, A. J. (2009a). Africa's Development in the Era of Barack Obama: The Role of the African Union. Journal of Pan African Studies, 2, 101-116.

Kaba, A. J. (2009b). Life Expectancy, Death Rates, Geography and Black People: A Statistical World Overview. Journal of Black Studies, 39, 337-347. https://doi.org/10.1177/0021934706293018

Kaba, A. J. (2014). The Paradoxes of Africa's Development: African Union's Contributions to Africa's Recent Achievements, 2005-2014. Journal of African Foreign Affairs, 1, 55-72.

Kaba, A. J. (2015). Explaining the Rapid Increase in Nigeria's Sex Ratio at Birth: Factors 
and Implications. African Journal of Reproductive Health, 19, 17-33.

Kaba, A. J. (2016). Africa: Development Challenges and Possibilities. Austin, TX: Pan-African University Press.

Kaba, A. J. (2017). Inheritance: The Net Worth of the 2011 Root Magazine's 100 Most Influential Young Black Americans. African Renaissance, 14, 139-170. https://doi.org/10.31920/2516-5305/2017/v14n1_2a8

Kaba, A. J., \& Nkweti-Kaba, A. (2020). COVID-19 in African Countries versus Other World Regions: A Review. African Journal of Reproductive Health June (Special Edition on COVID-19), 24, 125-141.

Khokhar, T., \& Kashiwase, H. (2015). The Future of the World's Population in 4 Charts. Washington DC: World Bank.

https://blogs.worldbank.org/opendata/future-world-s-population-4-charts

Knight Frank (2020). The Wealth Report. https://content.knightfrank.com/content/pdfs/global/the-wealth-report-2020.pdf

Kruys, G. P. H. (2008). Population Growth: Its Effect on Human Security with Emphasis on South Africa. Strategic Review for Southern Africa, 30, 40-64.

Martin, C. J. (1953). Some Estimates of the General Age Distribution, Fertility and Rate of Natural Increase of the African Population of British East Africa. Population Studies, 7, 181-199. https://doi.org/10.1080/00324728.1953.10415302

Mason, K. O. (1997). Explaining Fertility Transitions. Demography, 34, 443-454. https://doi.org/10.2307/3038299

Mazzucato, V., \& Niemeijer, D. (2002). Population Growth and the Environment in Africa: Local Informal Institutions, the Missing Link. Economic Geography, 78, 171-193. https://doi.org/10.2307/4140786

Mountford, A., \& Rapoport, H. (2016). Migration Policy, African Population Growth and Global Inequality. The World Economy, 39, 543-556. https://doi.org/10.1111/twec.12268

Mwichabe, S. (2014). The African Agrarian Ideology and the Food Security Challenge in Sub-Saharan Africa. Development, 56, 412-420. https://doi.org/10.1057/dev.2014.14

Raduzzi, A., \& Massey, J. E. (2019). Customers' Satisfaction and Brand Loyalty at McDonald's Maroc. African Journal of Marketing Management, 11, 21-34. https://doi.org/10.5897/AJMM2019.0599

Rashid, S. (1987). Malthus's Essay on Population: The Facts of "Super-Growth" and the Rhetoric of Scientific Persuasion. Journal of the History of the Behavioral Sciences, 23, 22-36. https://doi.org/10.1002/1520-6696(198701)23:1<22::AID-JHBS2300230104>3.0.CO;2-5

Rovin, K., Hardee, K., \& Aklilu, K. (2013). Linking Population, Fertility, and Family Planning with Adaptation to Climate Change: Perspectives from Ethiopia. African Journal of Reproductive Health, 17, 15-29.

UNAIDS (2006). 2006 Report on the Global AIDS Epidemic: A UNAIDS 10th Anniversary Special Edition. https://data.unaids.org/pub/report/2006/2006_gr_en.pdf

UNAIDS (2020). Fact Sheet: Global HIV Statistics. https://www.unaids.org/sites/default/files/media_asset/UNAIDS_FactSheet_en.pdf

UNESCO Institute for Statistics (2010) Trends in Tertiary Education: Sub-Saharan Africa. UIS Fact Sheet No. 10. http://uis.unesco.org/sites/default/files/documents/fs10-trends-in-tertiary-education-s ub-saharan-africa-2010-en.pdf 
United Nations Children's Fund (UNICEF) (2019). Maternal Mortality Ratio (MMR) Trends by Region.

https://data.unicef.org/topic/maternal-health/maternal-mortality/\#: :text=Sub\%2DSah aran\%20Africans\%20suffer\%20from,maternal\%20deaths\%20per\%20year\%20worldwide

United Nations Population Division. (2018). World Population Prospects: The 2017 Revision. https://population.un.org/wpp/Download/Standard/Population

United States Census Bureau (2020). U.S. and World Population Clock. https://www.census.gov/popclock/

Weil, D. N. (2008). Is It Africa's Turn? Rapid Population Growth Raises the Stakes for African Governments. Boston Review, 33, 16-17.

World Bank (2020) Educational Attainment, at Least Completed Short-Cycle Tertiary, Population 25+, Male (\%) (Cumulative)-Sub-Saharan Africa. Retrieved on July 25, 2020. https://data.worldbank.org/indicator/SE.TER.CUAT.ST.MA.ZS?locations=ZG

World Bank (2020). Educational Attainment, at Least Completed Short-Cycle Tertiary, Population 25+, Female (\%) (Cumulative)—Sub-Saharan Africa. https://data.worldbank.org/indicator/SE.TER.CUAT.ST.FE.ZS?locations=ZG

World Bank (2020). School Enrollment, Tertiary (\% Gross)—Sub-Saharan Africa. Washington DC. https://data.worldbank.org/indicator/SE.TER.ENRR?locations=ZG

World Bank (2020). Table 1.2 Estimates and Projections of Remittance Flows to Low-and Middle-Income Regions. COVID-19 Crisis through a Migration Lens. Migration and Development Brief 32. Washington DC.

https://openknowledge.worldbank.org/bitstream/handle/10986/33634/COVID-19-Crisi s-Through-a-Migration-Lens.pdf?sequence $=5$ \&isAllowed $=y$

Zinkina, J., \& Korotayev, A. (2013). Urbanization Dynamics in Egypt: Factors, Trends, Perspectives. Arab Studies Quarterly, 35, 20-38.

https://doi.org/10.13169/arabstudquar.35.1.0020

Zinkina, J., \& Korotayev, A. (2014). Explosive Population Growth in Tropical Africa: Crucial Omission in Development Forecasts-Emerging Risks and Way Out. World Futures, 70, 120-139. https://doi.org/10.1080/02604027.2014.894868

Zuberi, T., Sibanda, A., Bawah, A., \& Noumbissi, A. (2003). Population and African Society. Annual Review of Sociology, 29, 465-486.

https://doi.org/10.1146/annurev.soc.29.010202.100126 


\section{Appendices}

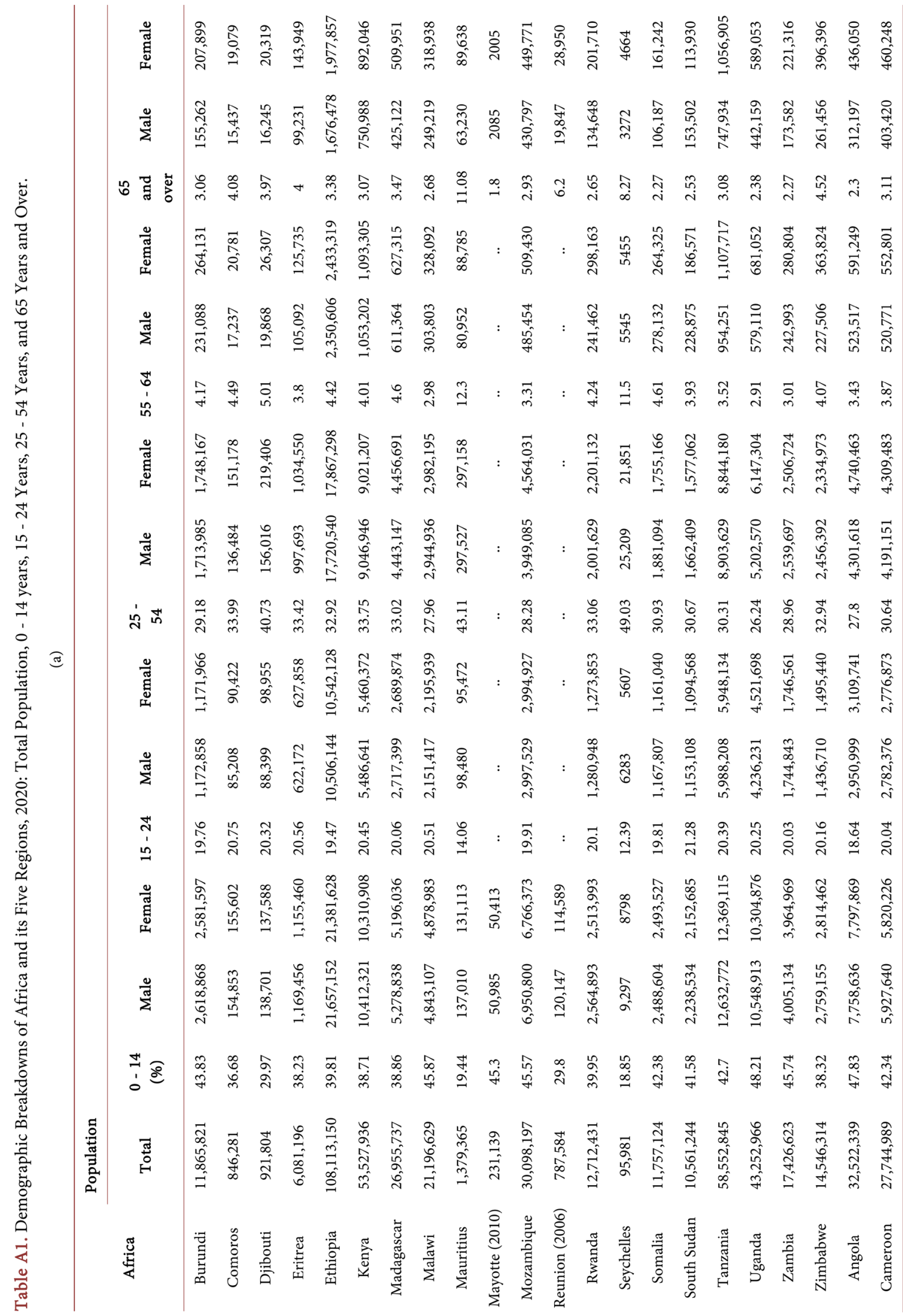




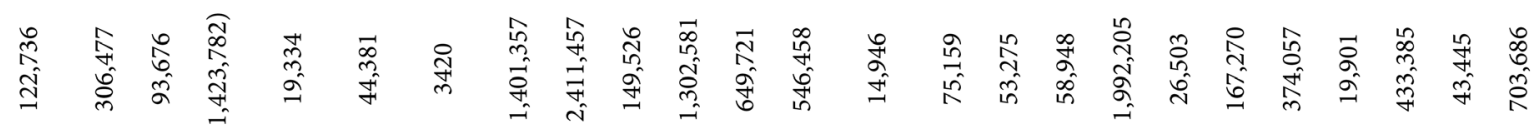

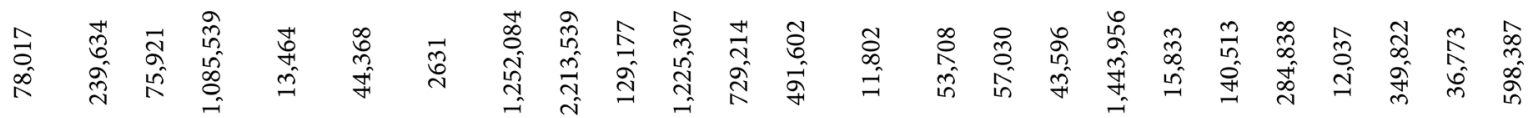

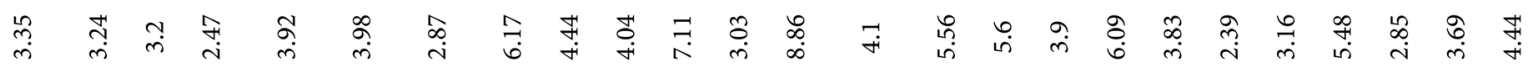

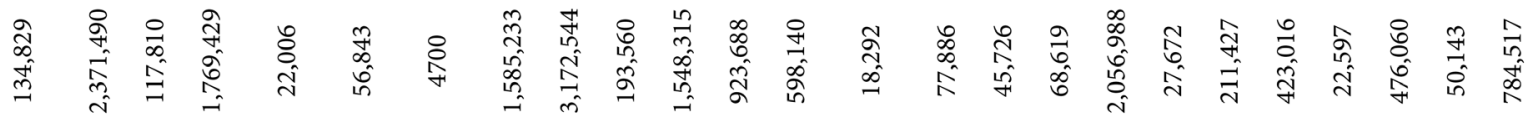

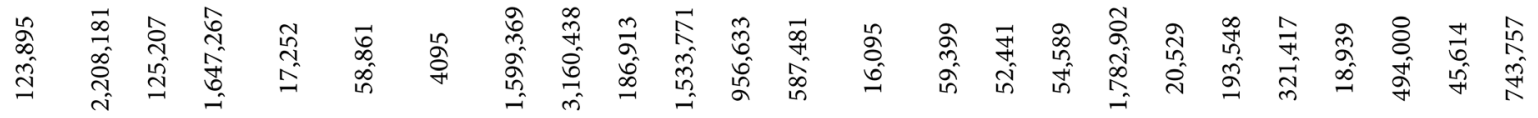

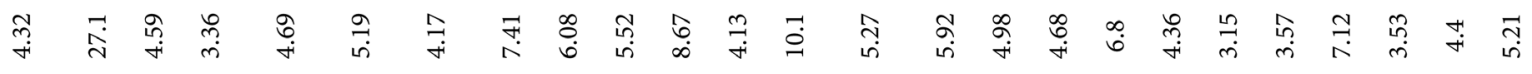

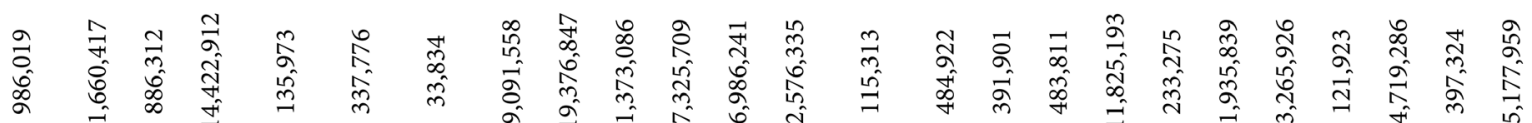

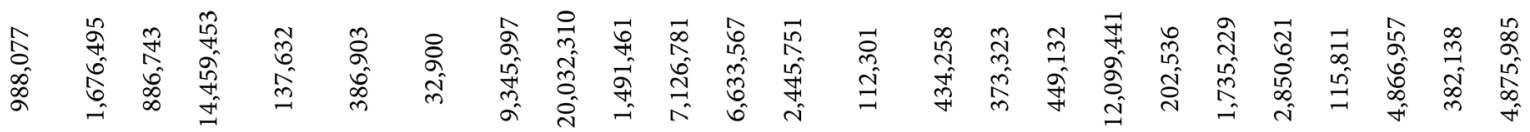

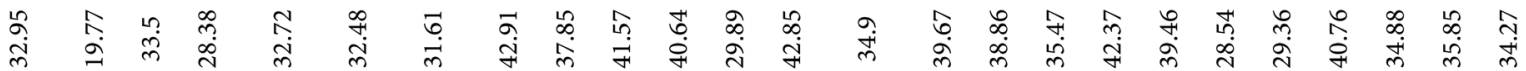

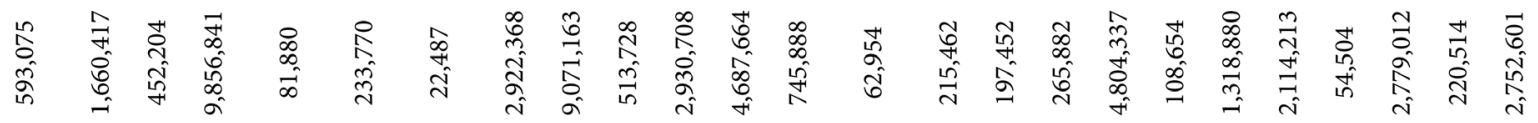

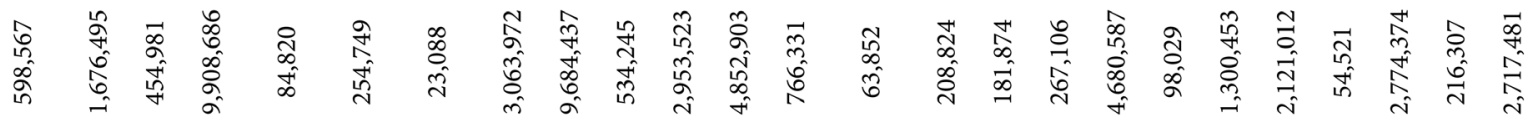

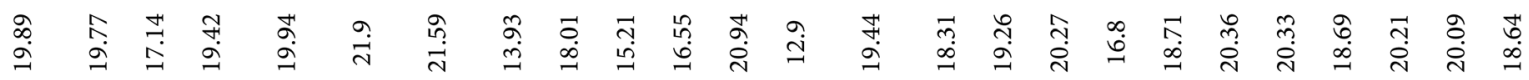

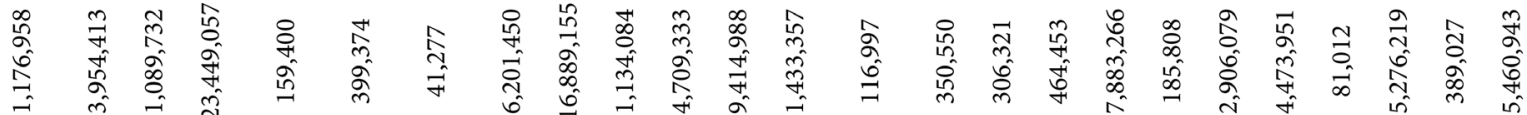

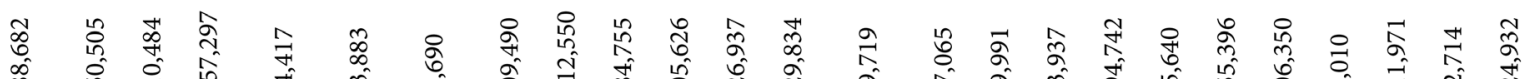

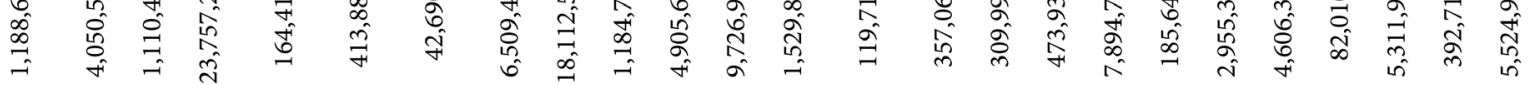

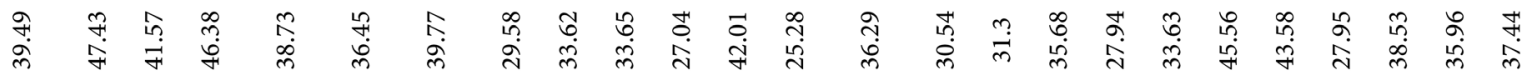

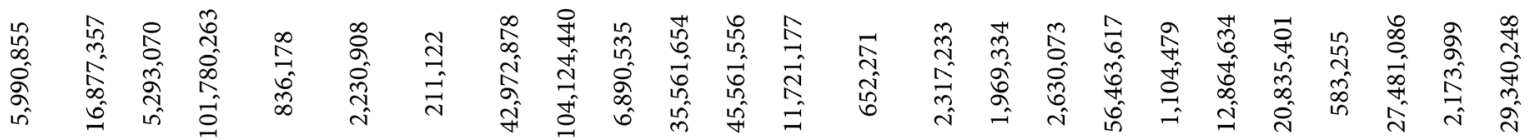

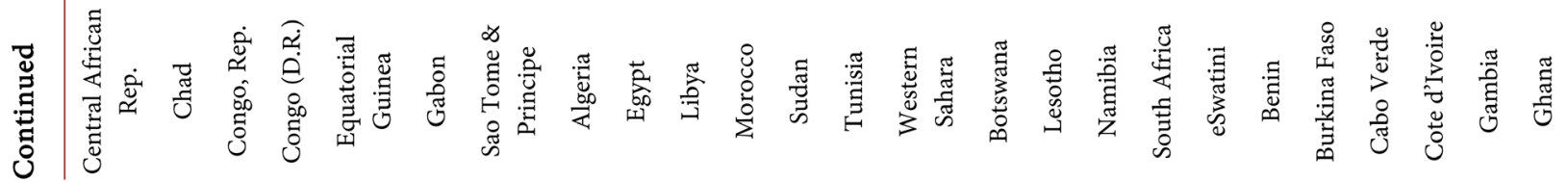




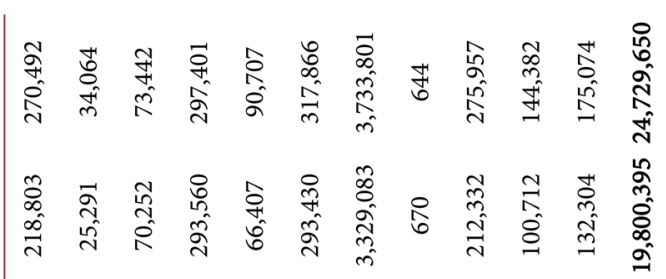

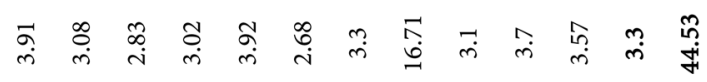

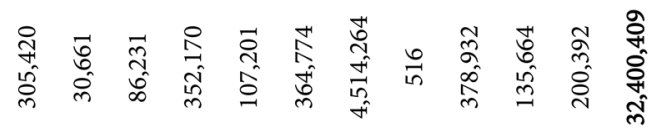

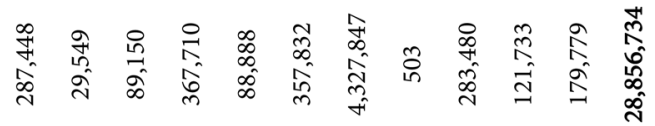

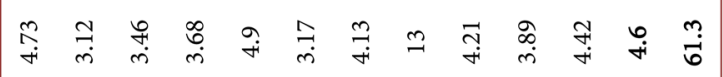

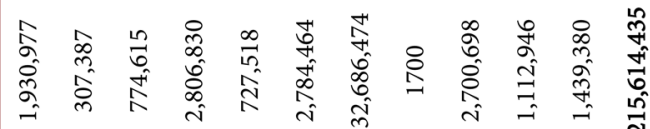

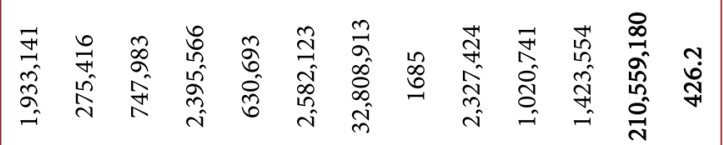

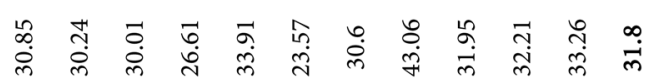

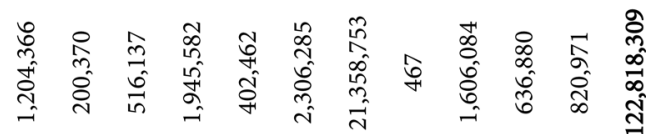

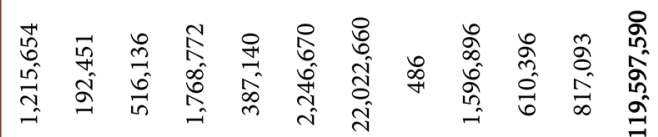

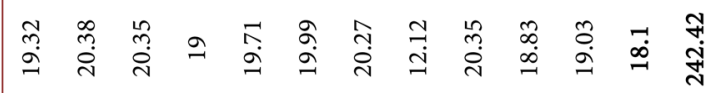

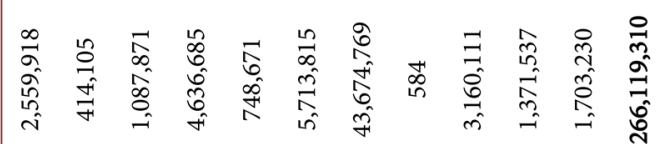

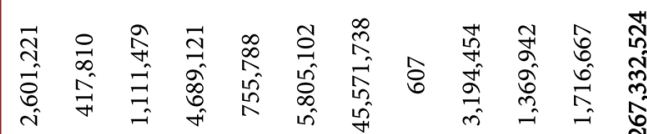

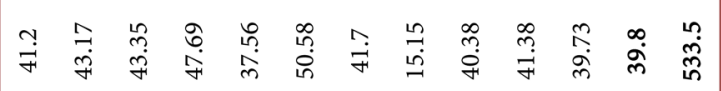

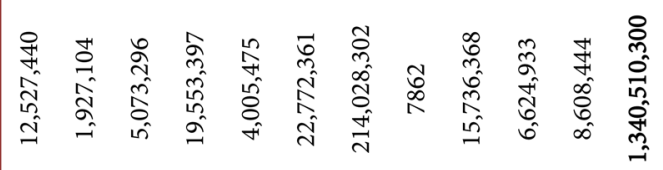

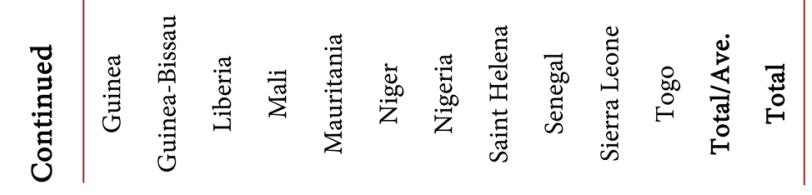

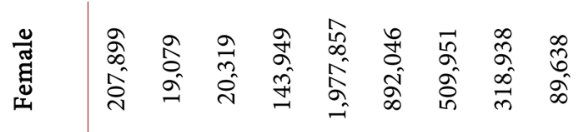

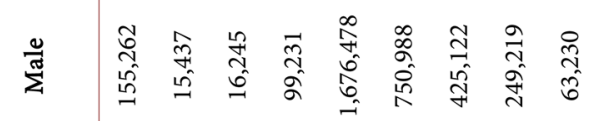

ڤి 芯

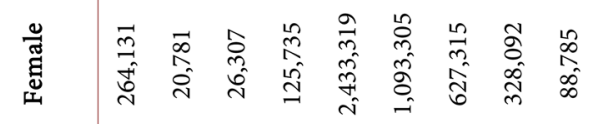

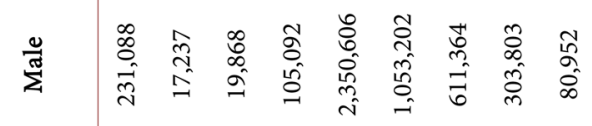

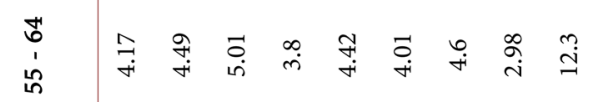

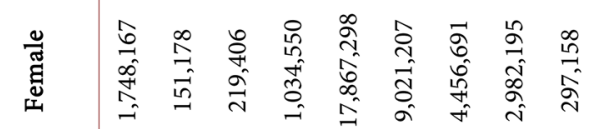

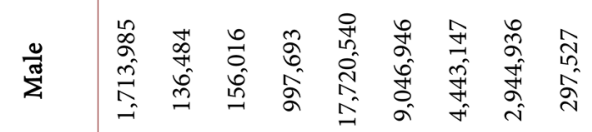

每

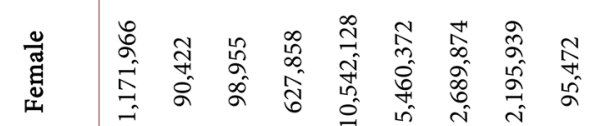

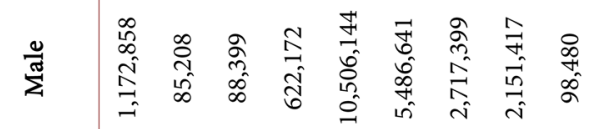

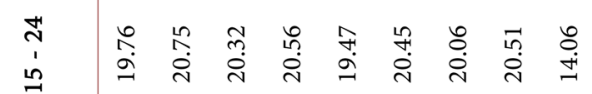

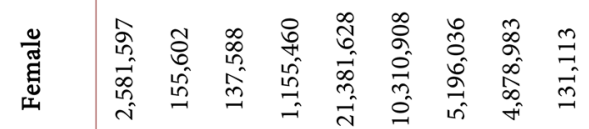

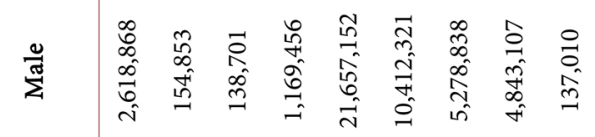

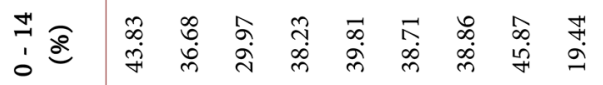

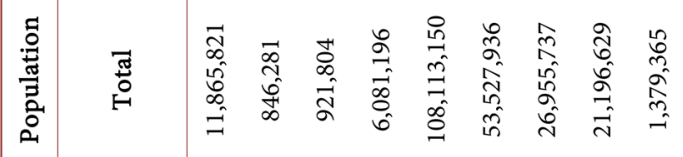

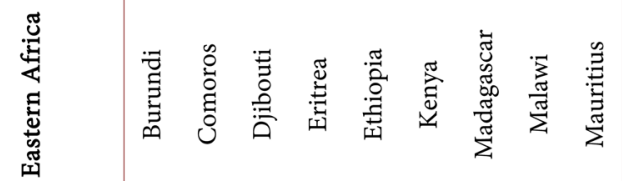




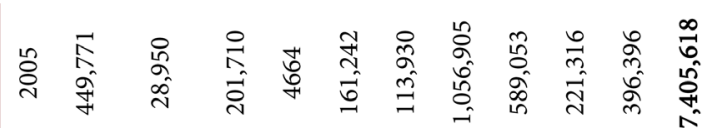

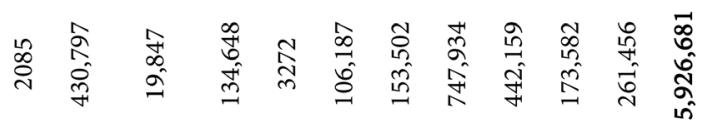

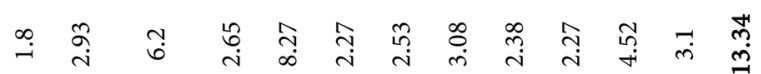

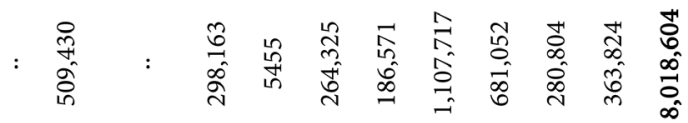

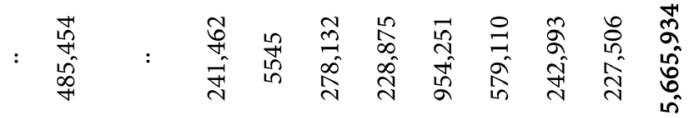

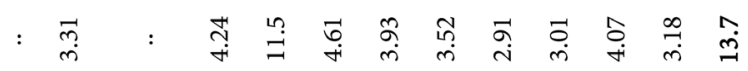

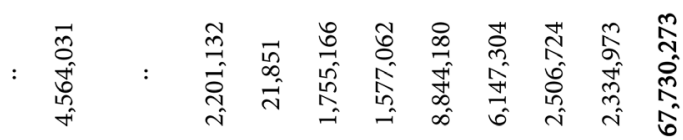

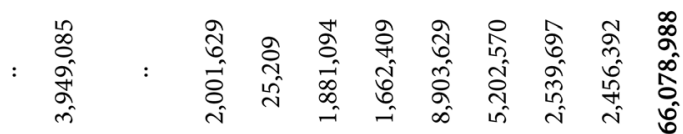

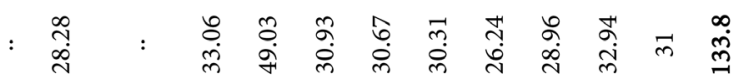

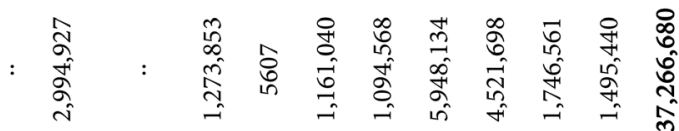

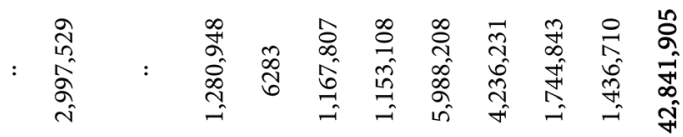

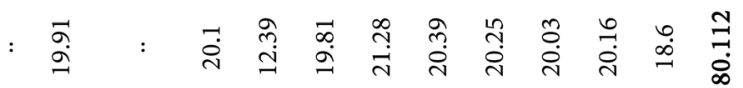

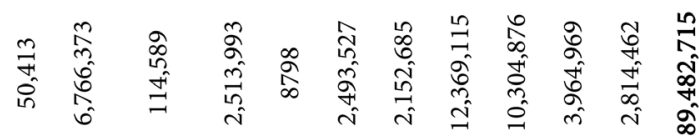

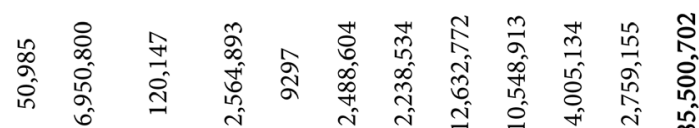

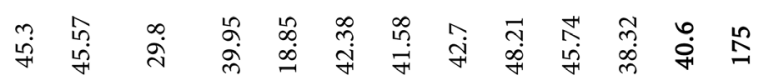

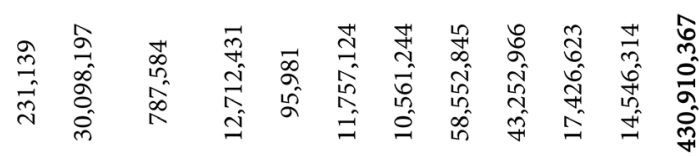

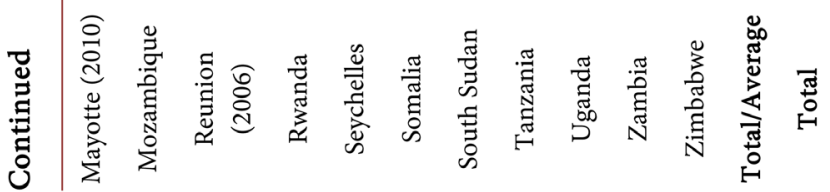

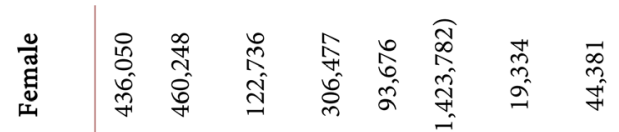

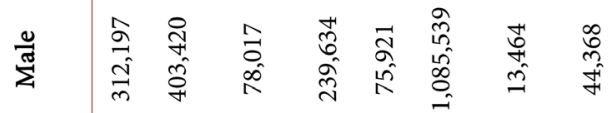

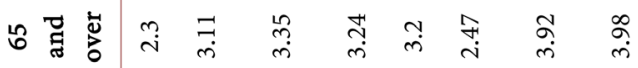

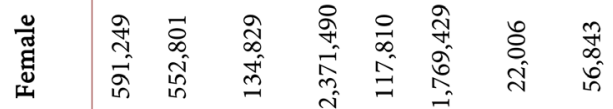

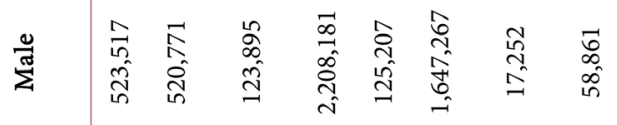

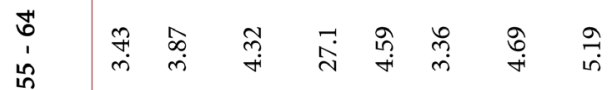

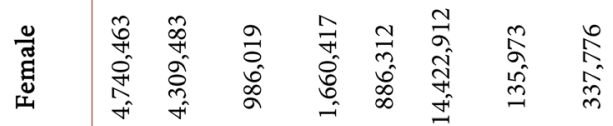

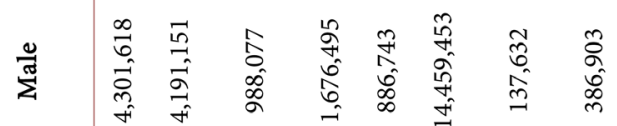

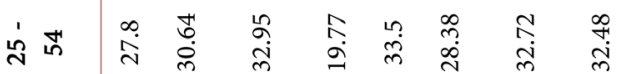

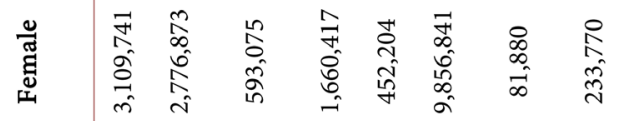

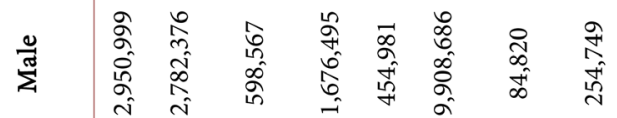

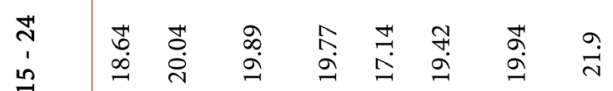

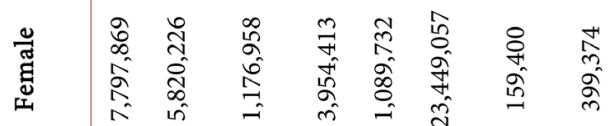

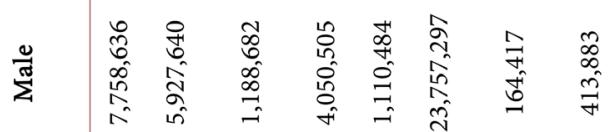

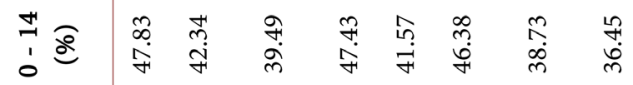

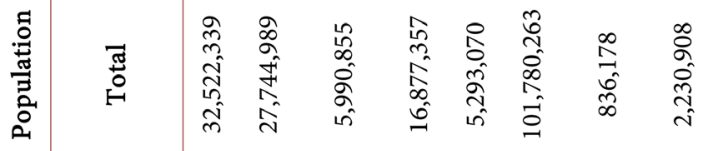

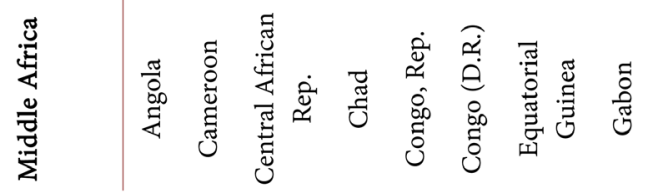




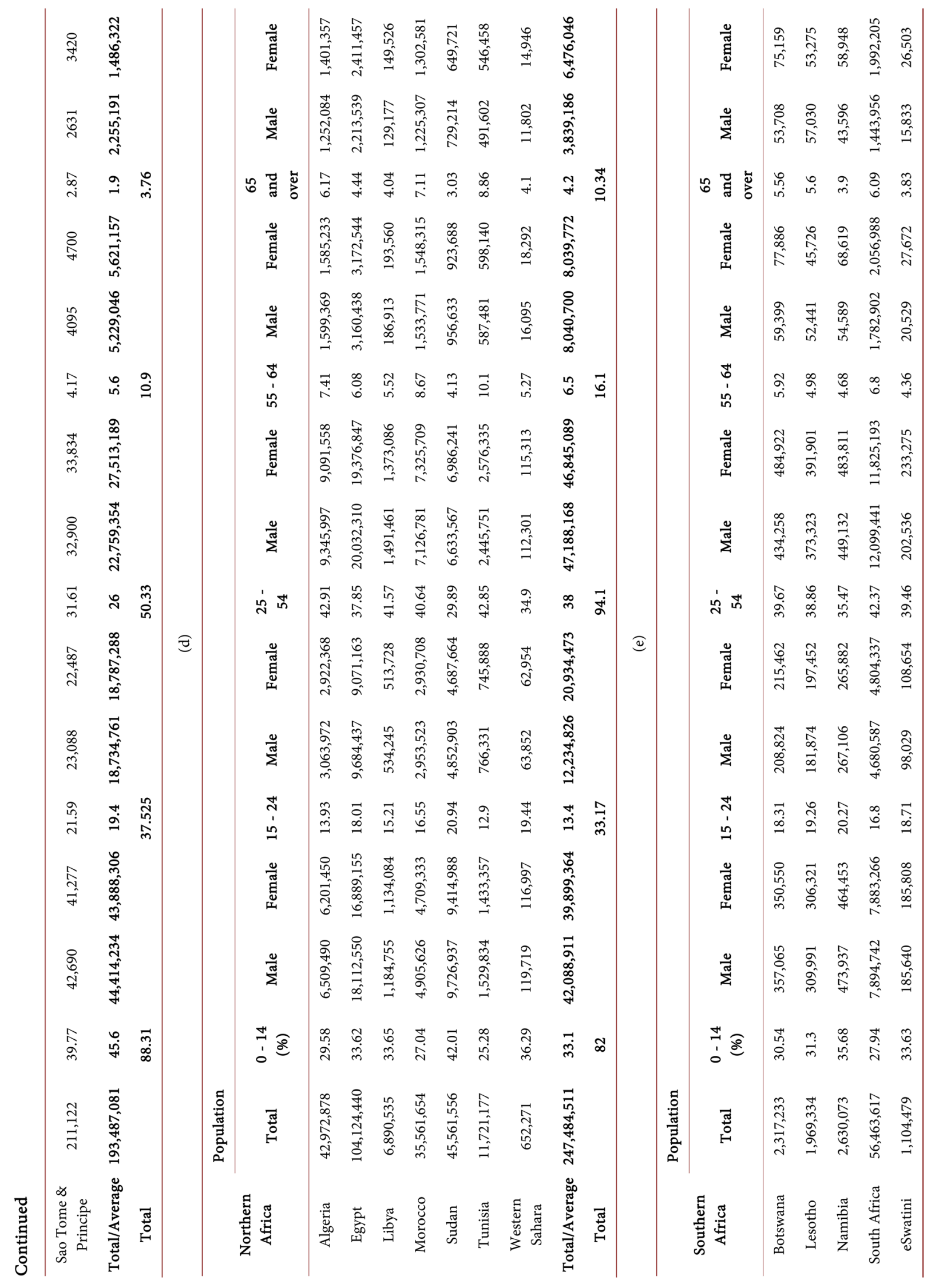




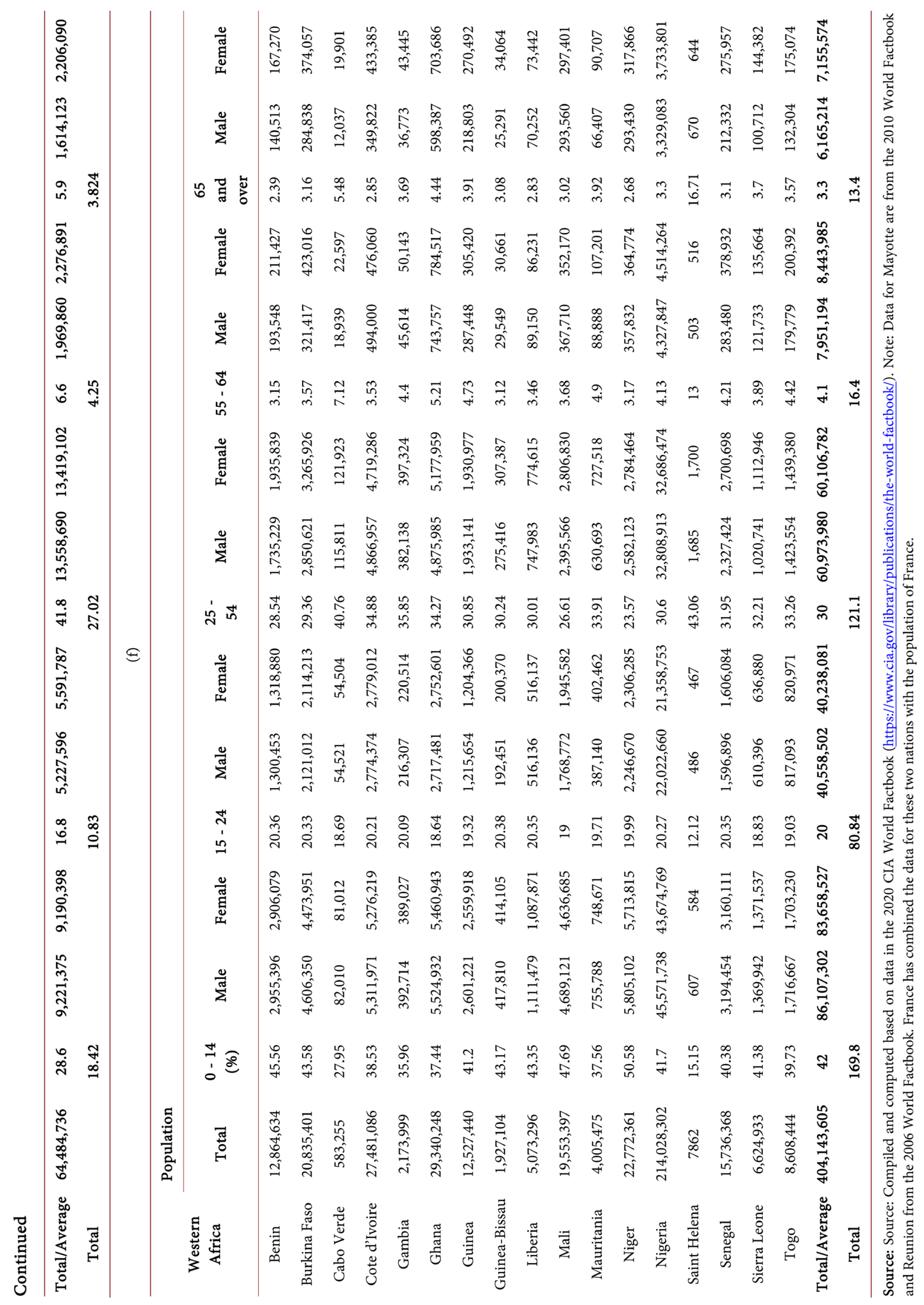


Table A2. Demographic Breakdowns of Africa and its Five Regions, 2020: Population growth, Increase, Infant Mortality, Life Expectancy, Total Fertility Rates, and Death Rates.

(a)

\begin{tabular}{|c|c|c|c|c|c|c|c|c|c|c|}
\hline $\begin{array}{c}\text { Africa } \\
\text { Country }\end{array}$ & $\begin{array}{c}\text { Population } \\
\text { growth rate } \\
\text { (\%) }\end{array}$ & $\begin{array}{l}\text { Birth rate } \\
\text { (per 1000) }\end{array}$ & $\begin{array}{c}\text { Infant } \\
\text { mortality rate } \\
(\text { Per } 1000)\end{array}$ & Male & Female & $\begin{array}{c}\text { Life expectancy } \\
\text { at birth (Years) } \\
\text { Total } \\
\text { population }\end{array}$ & Male & Female & $\begin{array}{l}\text { Total fertility } \\
\text { rate (children } \\
\text { born/woman) }\end{array}$ & $\begin{array}{c}\text { Death } \\
\text { rate (Per } \\
1000)\end{array}$ \\
\hline Burundi & 2.85 & 36.5 & 40.1 & 44.4 & 35.7 & 66.7 & 64.6 & 68.8 & 5.28 & 6.2 \\
\hline Comoros & 1.47 & 23.6 & 55 & 64.8 & 45.1 & 65.7 & 63.3 & 68.1 & 2.95 & 6.9 \\
\hline Djibouti & 2.07 & 22.7 & 41.6 & 47.9 & 35.2 & 64.7 & 62.1 & 67.4 & 2.19 & 7.3 \\
\hline Eritrea & 0.93 & 27.9 & 43.3 & 50.3 & 36.1 & 66.2 & 63.6 & 68.8 & 3.73 & 6.9 \\
\hline Ethiopia & 2.56 & 31.6 & 35.8 & 40.8 & 30.5 & 67.5 & 65.5 & 69.7 & 4.14 & 5.9 \\
\hline Kenya & 2.2 & 27.2 & 29.8 & 33 & 26.6 & 69 & 67.3 & 70.6 & 3.43 & 5.2 \\
\hline Madagascar & 2.39 & 29.9 & 37.8 & 41.5 & 34.1 & 67.3 & 65.7 & 68.9 & 3.78 & 6.2 \\
\hline Malawi & 3.3 & 40.1 & 39.5 & 45.8 & 33.2 & 63.2 & 61.2 & 65.3 & 5.31 & 7.2 \\
\hline Mauritius & 0.54 & 12.6 & 9 & 10.7 & 7.3 & 76.5 & 73 & 80.1 & 1.73 & 7.3 \\
\hline Mayotte (2010) & 3.3 & 38.76 & 54.75 & 60.23 & 49.09 & 63.28 & 60.99 & 65.63 & 5.4 & 7.05 \\
\hline Mozambique & 2.62 & 38.6 & 64.7 & 66.8 & 62.6 & 55.9 & 54.4 & 57.4 & 4.97 & 11 \\
\hline Reunion (2006) & 1.34 & 18.9 & 7.63 & 8.37 & 6.85 & 74.18 & 70.78 & 77.75 & 2.45 & 5.49 \\
\hline Rwanda & 2 & 27.9 & 28 & 30.6 & 25.3 & 65.1 & 63.2 & 67.1 & 3.52 & 6.1 \\
\hline Seychelles & 0.69 & 12.8 & 9.3 & 11.5 & 6.9 & 75.6 & 71.1 & 80.2 & 1.83 & 7.1 \\
\hline Somalia & 2.21 & 38.7 & 89.5 & 97.8 & 54 & 54 & 51.8 & 56.2 & 5.51 & 12.4 \\
\hline South Sudan & 2.7 & 38.8 & 69.9 & 76 & 63.5 & 55.5 & 54.6 & 56.5 & 5.54 & 11.4 \\
\hline Tanzania & 2.71 & 34.6 & 36.4 & 38.5 & 34.4 & 63.9 & 62.3 & 65.5 & 4.59 & 7.1 \\
\hline Uganda & 3.34 & 42.3 & 32.6 & 36.1 & 28.9 & 68.2 & 66 & 70.5 & 5.54 & 5.3 \\
\hline Zambia & 2.89 & 40.4 & 56 & 61.1 & 50.7 & 53.6 & 51.9 & 55.3 & 5.49 & 11.6 \\
\hline Zimbabwe & 1.87 & 33.6 & 30.3 & 34.2 & 26.4 & 62.3 & 60.2 & 64.5 & 3.93 & 9.3 \\
\hline Angola & 3.43 & 42.7 & 62.3 & 67.8 & 56.8 & 61.3 & 59.3 & 63.4 & 5.96 & 8.5 \\
\hline Cameroon & 2.78 & 36.3 & 51.5 & 56.5 & 46.3 & 62.3 & 60.6 & 64 & 4.66 & 8.1 \\
\hline Central African Rep. & 2.09 & 33.2 & 80.6 & 87.7 & 73.2 & 54.2 & 52.7 & 55.7 & 4.14 & 12.3 \\
\hline Chad & 3.18 & 41.7 & 68.6 & 74.5 & 62.5 & 58.3 & 56.5 & 60.1 & 5.68 & 10 \\
\hline Congo, Rep. & 2.26 & 32.6 & 50.7 & 55.3 & 45.9 & 61.3 & 59.9 & 62.7 & 4.45 & 8.7 \\
\hline Congo (D.R.) & 3.18 & 41 & 64.5 & 70.3 & 58.4 & 61 & 59.3 & 62.8 & 5.77 & 8.4 \\
\hline Equatorial Guinea & 2.35 & 30.7 & 59.7 & 60.8 & 58.6 & 65.7 & 64.4 & 66.9 & 4.11 & 7.3 \\
\hline Gabon & 2.5 & 26.3 & 30.4 & 33.6 & 27 & 69 & 67.3 & 70.8 & 3.41 & 5.9 \\
\hline Sao Tome \& Principe & 1.58 & 29.7 & 41.7 & 43.6 & 39.8 & 66.3 & 64.9 & 67.8 & 3.82 & 6.3 \\
\hline Algeria & 1.52 & 20 & 17.6 & 19.1 & 16 & 77.5 & 76.1 & 79.1 & 2.59 & 4.4 \\
\hline Egypt & 2.28 & 27.2 & 17.1 & 18.2 & 15.8 & 73.7 & 72.3 & 75.3 & 3.29 & 4.4 \\
\hline Libya & 1.94 & 23 & 11.5 & 12.9 & 10 & 76.7 & 74.4 & 79.1 & 3.17 & 3.5 \\
\hline
\end{tabular}


Continued

\begin{tabular}{|c|c|c|c|c|c|c|c|c|c|c|}
\hline Morocco & 0.96 & 17.9 & 18.2 & 20.2 & 16.1 & 73.3 & 71.6 & 75.1 & 2.31 & 6.6 \\
\hline Sudan & 2.69 & 33.8 & 41.8 & 46.7 & 36.6 & 66.5 & 64.3 & 68.8 & 4.72 & 6.5 \\
\hline Tunisia & 0.85 & 15.9 & 11 & 12 & 9.8 & 76.3 & 74.6 & 78.1 & 2.06 & 6.4 \\
\hline Western Sahara & 2.54 & 28 & 47.9 & 52.5 & 43.1 & 64.5 & 62.1 & 67 & 3.65 & 7.7 \\
\hline Botswana & 1.48 & 20.9 & 26.8 & 29.2 & 24.2 & 64.8 & 62.8 & 66.9 & 2.45 & 9.2 \\
\hline Lesotho & 0.16 & 23.2 & 41.5 & 44.8 & 38.1 & 53 & 53.1 & 53 & 2.5 & 15.4 \\
\hline Namibia & 1.86 & 25.7 & 31.4 & 33.5 & 29.2 & 65.3 & 63.3 & 67.3 & 3.07 & 7.3 \\
\hline South Africa & 0.97 & 19.2 & 27.8 & 31 & 24.6 & 64.8 & 63.4 & 66.2 & 2.22 & 9.3 \\
\hline Swaziland & 0.77 & 24.5 & 42.8 & 47.3 & 38.2 & 58.6 & 56.5 & 60.7 & 2.52 & 10.1 \\
\hline Benin & 3.4 & 42.1 & 58.7 & 63.9 & 53.3 & 61.4 & 59.6 & 63.3 & 5.53 & 8.4 \\
\hline Burkina Faso & 2.66 & 35.1 & 52 & 56.4 & 47.5 & 62.7 & 60.9 & 64.5 & 4.51 & 8.2 \\
\hline Cape Verde & 1.28 & 19.1 & 19.7 & 22.7 & 16.7 & 73.2 & 70.8 & 75.6 & 2.16 & 5.9 \\
\hline Cote d'Ivoire & 2.26 & 29.1 & 59.1 & 66.7 & 51.2 & 61.3 & 59.2 & 63.6 & 3.67 & 7.9 \\
\hline Gambia & 1.87 & 27 & 54.9 & 60.1 & 49.6 & 65.8 & 63.5 & 68.3 & 3.21 & 6.7 \\
\hline Ghana & 2.15 & 29.6 & 32.1 & 35.9 & 28.2 & 68.2 & 65.6 & 70.8 & 3.9 & 6.6 \\
\hline Guinea & 2.76 & 36.1 & 52.4 & 57.3 & 47.3 & 63.2 & 61.3 & 65 & 4.92 & 8.4 \\
\hline Guinea-Bissau & 2.51 & 36.9 & 51.9 & 57.9 & 45.7 & 62.8 & 60.6 & 65.1 & 4.75 & 7.9 \\
\hline Liberia & 2.71 & 37.3 & 47.4 & 51.7 & 43.1 & 64.7 & 62.5 & 67 & 4.9 & 7 \\
\hline Mali & 2.95 & 42.2 & 64 & 69.6 & 58.3 & 61.6 & 59.4 & 63.9 & 5.72 & 9 \\
\hline Mauritania & 2.09 & 29 & 47.9 & 52.5 & 43.1 & 64.5 & 62.1 & 67 & 3.65 & 7.5 \\
\hline Niger & 3.66 & 47.5 & 67.7 & 72 & 63.3 & 59.3 & 57.8 & 60.8 & 7 & 10.2 \\
\hline Nigeria & 2.53 & 34.6 & 59.8 & 65.4 & 54 & 60.4 & 58.6 & 62.3 & 4.72 & 9.1 \\
\hline Saint Helena & 0.13 & 9.4 & 12 & 14.1 & 9.7 & 80 & 77.1 & 83.1 & 1.6 & 8.3 \\
\hline Senegal & 2.31 & 31.8 & 45.7 & 51.3 & 40 & 63.2 & 61.1 & 65.4 & 4.04 & 7.6 \\
\hline Sierra Leone & 2.43 & 35.4 & 63.6 & 71.6 & 55.4 & 59.8 & 57.1 & 62.6 & 4.62 & 9.8 \\
\hline Togo & 2.56 & 32 & 38.5 & 44.5 & 32.3 & 66.6 & 63.9 & 69.3 & 4.22 & 6.5 \\
\hline Average & 2.5 & 30.4 & 42.8 & 47.4 & 38.0 & 65 & & & 4.3 & 7.8 \\
\hline
\end{tabular}

(b)

\begin{tabular}{|c|c|c|c|c|c|c|c|c|c|c|}
\hline Eastern Africa & $\begin{array}{c}\text { Population } \\
\text { growth rate } \\
(\%)\end{array}$ & $\begin{array}{l}\text { Birth rate } \\
\text { (per 1000) }\end{array}$ & $\begin{array}{c}\text { Infant } \\
\text { mortality rate } \\
(\text { Per } 1000)\end{array}$ & Male & Female & $\begin{array}{c}\text { Life expectancy } \\
\text { at birth (Years) } \\
\text { Total } \\
\text { population }\end{array}$ & Male & Female & $\begin{array}{l}\text { Total fertility } \\
\text { rate (children } \\
\text { born/woman) }\end{array}$ & $\begin{array}{c}\text { Death } \\
\text { rate (Per } \\
1000)\end{array}$ \\
\hline Burundi & 2.85 & 36.5 & 40.1 & 44.4 & 35.7 & 66.7 & 64.6 & 68.8 & 5.28 & 6.2 \\
\hline Comoros & 1.47 & 23.6 & 55 & 64.8 & 45.1 & 65.7 & 63.3 & 68.1 & 2.95 & 6.9 \\
\hline Djibouti & 2.07 & 22.7 & 41.6 & 47.9 & 35.2 & 64.7 & 62.1 & 67.4 & 2.19 & 7.3 \\
\hline Eritrea & 0.93 & 27.9 & 43.3 & 50.3 & 36.1 & 66.2 & 63.6 & 68.8 & 3.73 & 6.9 \\
\hline Ethiopia & 2.56 & 31.6 & 35.8 & 40.8 & 30.5 & 67.5 & 65.5 & 69.7 & 4.14 & 5.9 \\
\hline Kenya & 2.2 & 27.2 & 29.8 & 33 & 26.6 & 69 & 67.3 & 70.6 & 3.43 & 5.2 \\
\hline
\end{tabular}




\section{Continued}

\begin{tabular}{|c|c|c|c|c|c|c|c|c|c|c|}
\hline Madagascar & 2.39 & 29.9 & 37.8 & 41.5 & 34.1 & 67.3 & 65.7 & 68.9 & 3.78 & 6.2 \\
\hline Malawi & 3.3 & 40.1 & 39.5 & 45.8 & 33.2 & 63.2 & 61.2 & 65.3 & 5.31 & 7.2 \\
\hline Mauritius & 0.54 & 12.6 & 9 & 10.7 & 7.3 & 76.5 & 73 & 80.1 & 1.73 & 7.3 \\
\hline Mayotte (2010) & 3.2 & 38.76 & 54.75 & 60.23 & 49.09 & 63.28 & 60.99 & 65.63 & 5.4 & 7.05 \\
\hline Mozambique & 2.62 & 38.6 & 64.7 & 66.8 & 62.6 & 55.9 & 54.4 & 57.4 & 4.97 & 11 \\
\hline Reunion (2006) & 1.34 & 18.9 & 7.63 & 8.37 & 6.85 & 74.18 & 70.78 & 77.75 & 2.45 & 5.49 \\
\hline Rwanda & 2 & 27.9 & 28 & 30.6 & 25.3 & 65.1 & 63.2 & 67.1 & 3.52 & 6.1 \\
\hline Seychelles & 0.69 & 12.8 & 9.3 & 11.5 & 6.9 & 75.6 & 71.1 & 80.2 & 1.83 & 7.1 \\
\hline Somalia & 2.21 & 38.7 & 89.5 & 97.8 & 54 & 54 & 51.8 & 56.2 & 5.51 & 12.4 \\
\hline Tanzania & 2.71 & 34.6 & 36.4 & 38.5 & 34.4 & 63.9 & 62.3 & 65.5 & 4.59 & 7.1 \\
\hline Uganda & 3.34 & 42.3 & 32.6 & 36.1 & 28.9 & 68.2 & 66 & 70.5 & 5.54 & 5.3 \\
\hline Zambia & 2.89 & 40.4 & 56 & 61.1 & 50.7 & 53.6 & 51.9 & 55.3 & 5.49 & 11.6 \\
\hline Zimbabwe & 1.87 & 33.6 & 30.3 & 34.2 & 26.4 & 62.3 & 60.2 & 64.5 & 3.93 & 9.3 \\
\hline Average & & 30.9 & 40.5 & 45.7 & 34.6 & & & & & 7.6 \\
\hline
\end{tabular}

(c)

\begin{tabular}{|c|c|c|c|c|c|c|c|c|c|c|}
\hline Middle Africa & $\begin{array}{c}\text { Population } \\
\text { growth rate } \\
\qquad(\%)\end{array}$ & $\begin{array}{l}\text { Birth rate } \\
\text { (per 1000) }\end{array}$ & $\begin{array}{c}\text { Infant } \\
\text { mortality rate } \\
(\text { Per } 1000)\end{array}$ & Male & Female & $\begin{array}{c}\text { Life expectancy } \\
\text { at birth (Years) } \\
\text { Total } \\
\text { population }\end{array}$ & Male & Female & $\begin{array}{l}\text { Total fertility } \\
\text { rate (children } \\
\text { born/woman) }\end{array}$ & $\begin{array}{c}\text { Death } \\
\text { rate (Per } \\
1000)\end{array}$ \\
\hline Angola & 3.43 & 42.7 & 62.3 & 67.8 & 56.8 & 61.3 & 59.3 & 63.4 & 5.96 & 8.5 \\
\hline Cameroon & 2.78 & 36.3 & 51.5 & 56.5 & 46.3 & 62.3 & 60.6 & 64 & 4.66 & 8.1 \\
\hline Central African Rep. & 2.09 & 33.2 & 80.6 & 87.7 & 73.2 & 54.2 & 52.7 & 55.7 & 4.14 & 12.3 \\
\hline Chad & 3.18 & 41.7 & 68.6 & 74.5 & 62.5 & 58.3 & 56.5 & 60.1 & 5.68 & 10 \\
\hline Congo, Rep. & 2.26 & 32.6 & 50.7 & 55.3 & 45.9 & 61.3 & 59.9 & 62.7 & 4.45 & 8.7 \\
\hline Congo (D.R.) & 3.18 & 41 & 64.5 & 70.3 & 58.4 & 61 & 59.3 & 62.8 & 5.77 & 8.4 \\
\hline Equatorial Guinea & 2.35 & 30.7 & 59.7 & 60.8 & 58.6 & 65.7 & 64.4 & 66.9 & 4.11 & 7.3 \\
\hline Gabon & 2.5 & 26.3 & 30.4 & 33.6 & 27 & 69 & 67.3 & 70.8 & 3.41 & 5.9 \\
\hline Sao Tome \& Principe & 1.58 & 29.7 & 41.7 & 43.6 & 39.8 & 66.3 & 64.9 & 67.8 & 3.82 & 6.3 \\
\hline Average & & 34.9 & 56.7 & 61.1 & 52.1 & & & & & 8.4 \\
\hline
\end{tabular}

(d)

\begin{tabular}{cccccccccccc}
\hline & $\begin{array}{c}\text { Population } \\
\text { growth rate } \\
(\%)\end{array}$ & $\begin{array}{c}\text { Birth rate } \\
\text { (per 1000) }\end{array}$ & $\begin{array}{c}\text { Infant } \\
\text { mortality rate } \\
\text { (Per 1000) }\end{array}$ & Male & Female & $\begin{array}{c}\text { Life expectancy } \\
\text { at birth (Years) } \\
\text { Total } \\
\text { population }\end{array}$ & Male & $\begin{array}{c}\text { Total fertility } \\
\text { Female rate (children rate (Per } \\
\text { born/woman) } \\
\text { 1000) }\end{array}$ \\
\hline Algeria & 1.52 & 20 & 17.6 & 19.1 & 16 & 77.5 & 76.1 & 79.1 & 2.59 & 4.4 \\
Egypt & 2.28 & 27.2 & 17.1 & 18.2 & 15.8 & 73.7 & 72.3 & 75.3 & 3.29 & 4.4 \\
Libya & 1.94 & 23 & 11.5 & 12.9 & 10 & 76.7 & 74.4 & 79.1 & 3.17 & 3.5 \\
Morocco & 0.96 & 17.9 & 18.2 & 20.2 & 16.1 & 73.3 & 71.6 & 75.1 & 2.31 & 6.6 \\
\hline
\end{tabular}


Continued

\begin{tabular}{ccccccccccc}
\hline Sudan & 2.69 & 33.8 & 41.8 & 46.7 & 36.6 & 66.5 & 64.3 & 68.8 & 4.72 & 6.5 \\
Tunisia & 0.85 & 15.9 & 11 & 12 & 9.8 & 76.3 & 74.6 & 78.1 & 2.06 & 6.4 \\
Western Sahara & 2.54 & 28 & 47.9 & 52.5 & 43.1 & 64.5 & 62.1 & 67 & 3.65 & 7.7 \\
Average & & 23.7 & $\mathbf{2 0 . 6}$ & $\mathbf{2 5 . 9}$ & $\mathbf{2 1 . 1}$ & & & & & \\
\hline
\end{tabular}

(e)

\begin{tabular}{|c|c|c|c|c|c|c|c|c|c|c|}
\hline Southern Africa & $\begin{array}{c}\text { Population } \\
\text { growth rate } \\
\text { (\%) }\end{array}$ & $\begin{array}{l}\text { Birth rate } \\
\text { (per 1000) }\end{array}$ & $\begin{array}{c}\text { Infant } \\
\text { mortality rate } \\
(\text { Per } 1000)\end{array}$ & Male & Female & $\begin{array}{c}\text { Life expectancy } \\
\text { at birth (Years) } \\
\text { Total } \\
\text { population }\end{array}$ & Male & Female & $\begin{array}{l}\text { Total fertility } \\
\text { rate (children } \\
\text { born/woman) }\end{array}$ & $\begin{array}{c}\text { Death } \\
\text { rate }(\text { Per } \\
1000)\end{array}$ \\
\hline Botswana & 1.48 & 20.9 & 26.8 & 29.2 & 24.2 & 64.8 & 62.8 & 66.9 & 2.45 & 9.2 \\
\hline Lesotho & 0.16 & 23.2 & 41.5 & 44.8 & 38.1 & 53 & 53.1 & 53 & 2.5 & 15.4 \\
\hline Namibia & 1.86 & 25.7 & 31.4 & 33.5 & 29.2 & 65.3 & 63.3 & 67.3 & 3.07 & 7.3 \\
\hline South Africa & 0.97 & 19.2 & 27.8 & 31 & 24.6 & 64.8 & 63.4 & 66.2 & 2.22 & 9.3 \\
\hline Swaziland & 0.77 & 24.5 & 42.8 & 47.3 & 38.2 & 58.6 & 56.5 & 60.7 & 2.52 & 10.1 \\
\hline Average & & 22.7 & 34.1 & 37.2 & 30.9 & & & & & 10.3 \\
\hline
\end{tabular}

$(\mathrm{f})$

\begin{tabular}{|c|c|c|c|c|c|c|c|c|c|c|}
\hline Western Africa & $\begin{array}{c}\text { Population } \\
\text { growth rate } \\
\text { (\%) }\end{array}$ & $\begin{array}{l}\text { Birth rate } \\
\text { (per 1000) }\end{array}$ & $\begin{array}{c}\text { Infant } \\
\text { mortality rate } \\
(\text { Per 1000) }\end{array}$ & Male & Female & $\begin{array}{c}\text { Life expectancy } \\
\text { at birth (Years) } \\
\text { Total } \\
\text { population }\end{array}$ & Male & Female & $\begin{array}{l}\text { Total fertility } \\
\text { rate (children } \\
\text { born/woman) }\end{array}$ & $\begin{array}{c}\text { Death } \\
\text { rate }(\text { Per } \\
1000)\end{array}$ \\
\hline Benin & 3.4 & 42.1 & 58.7 & 63.9 & 53.3 & 61.4 & 59.6 & 63.3 & 5.53 & 8.4 \\
\hline Burkina Faso & 2.66 & 35.1 & 52 & 56.4 & 47.5 & 62.7 & 60.9 & 64.5 & 4.51 & 8.2 \\
\hline Cape Verde & 1.28 & 19.1 & 19.7 & 22.7 & 16.7 & 73.2 & 70.8 & 75.6 & 2.16 & 5.9 \\
\hline Cote d'Ivoire & 2.26 & 29.1 & 59.1 & 66.7 & 51.2 & 61.3 & 59.2 & 63.6 & 3.67 & 7.9 \\
\hline Gambia & 1.87 & 27 & 54.9 & 60.1 & 49.6 & 65.8 & 63.5 & 68.3 & 3.21 & 6.7 \\
\hline Ghana & 2.15 & 29.6 & 32.1 & 35.9 & 28.2 & 68.2 & 65.6 & 70.8 & 3.9 & 6.6 \\
\hline Guinea & 2.76 & 36.1 & 52.4 & 57.3 & 47.3 & 63.2 & 61.3 & 65 & 4.92 & 8.4 \\
\hline Guinea-Bissau & 2.51 & 36.9 & 51.9 & 57.9 & 45.7 & 62.8 & 60.6 & 65.1 & 4.75 & 7.9 \\
\hline Liberia & 2.71 & 37.3 & 47.4 & 51.7 & 43.1 & 64.7 & 62.5 & 67 & 4.9 & 7 \\
\hline Mali & 2.95 & 42.2 & 64 & 69.6 & 58.3 & 61.6 & 59.4 & 63.9 & 5.72 & 9 \\
\hline Mauritania & 2.09 & 29 & 47.9 & 52.5 & 43.1 & 64.5 & 62.1 & 67 & 3.65 & 7.5 \\
\hline Niger & 3.66 & 47.5 & 67.7 & 72 & 63.3 & 59.3 & 57.8 & 60.8 & 7 & 10.2 \\
\hline Nigeria & 2.53 & 34.6 & 59.8 & 65.4 & 54 & 60.4 & 58.6 & 62.3 & 4.72 & 9.1 \\
\hline Saint Helena & 0.13 & 9.4 & 12 & 14.1 & 9.7 & 80 & 77.1 & 83.1 & 1.6 & 8.3 \\
\hline Senegal & 2.31 & 31.8 & 45.7 & 51.3 & 40 & 63.2 & 61.1 & 65.4 & 4.04 & 7.6 \\
\hline Sierra Leone & 2.43 & 35.4 & 63.6 & 71.6 & 55.4 & 59.8 & 57.1 & 62.6 & 4.62 & 9.8 \\
\hline Togo & 2.56 & 32 & 38.5 & 44.5 & 32.3 & 66.6 & 63.9 & 69.3 & 4.22 & 6.5 \\
\hline Average & & 32.6 & 48.7 & 53.7 & 43.5 & & & & & 7.9 \\
\hline
\end{tabular}

Source: Compiled and computed based on data in the 2020 CIA World Factbook (https://www.cia.gov/library/publications/the-world-factbook/); The percent population growth rate, life expectancy, and total fertility rate data for Africa as a whole are from "Demographic Overview-UN-Africa-TOTAL FOR SELECTED REGION", United States Census Bureau. Retrieved on July 24, 2020 from:

https://www.census.gov/data-tools/demo/idb/region.php? $\mathrm{T}=13 \& \mathrm{RT}=0 \& \mathrm{~A}=$ both $\& \mathrm{Y}=2020 \& \mathrm{C}=\& \mathrm{R}=110$. Note: Data for Mayotte are from the $2010 \mathrm{World}$ Factbook and Reunion from the 2006 World Factbook. France has combined the data for these two nations with the population of France. 
Table A3. Demographic and Health Characteristics of Africa and its Five Regions: Median Age, Obesity Rates, Maternal Mortality Ratees, and Contraceptive Prevalence Use.

(a)

\begin{tabular}{|c|c|c|c|c|c|c|c|}
\hline Africa & $\begin{array}{c}\text { Median age } \\
\text { Total (2020 est.) }\end{array}$ & Male & Female & $\begin{array}{c}\text { Obesity } \\
\text { Pre. Rate \% } \\
\text { (2016 est.) }\end{array}$ & $\begin{array}{l}\text { Mother's mean } \\
\text { age at first birth }\end{array}$ & $\begin{array}{c}\text { Maternal } \\
\text { Mortality Rate } \\
\text { per } 100,000(2017 \text { est. })\end{array}$ & $\begin{array}{c}\text { Contraceptive } \\
\text { Preve. Use \% }\end{array}$ \\
\hline Burundi & 17.7 & 17.4 & 18 & 5.4 & 21.3 (2010 est.) & 548 & $28.5(2016 / 17)$ \\
\hline Comoros & 20.9 & 20.2 & 21.5 & 7.8 & 24.6 (2012 est.) & 273 & $19.4(2012)$ \\
\hline Djibouti & 24.9 & 23 & 26.4 & 13.5 & & 248 & $19(2012)$ \\
\hline Eritrea & 20.3 & 19.7 & 20.8 & 5 & 21.3 (2010 est.) & 480 & $8.4(2010)$ \\
\hline Ethiopia & 19.8 & 19.6 & 20.1 & 4.5 & 20 (2016 est.) & 401 & $40.1(2018)$ \\
\hline Kenya & 20 & 19.9 & 20.1 & 7.1 & 20.3 (2014 est.) & 342 & $60.5(2017)$ \\
\hline Madagascar & 20.3 & 20.1 & 20.5 & 5.3 & 19.5 (2008/09 est.) & 335 & $47.9(2017)$ \\
\hline Malawi & 16.8 & 16.7 & 16.9 & 5.8 & 18.9 (2015/16 est.) & 349 & $59.2(2015 / 16)$ \\
\hline Mauritius & 36.3 & 35 & 37.6 & 10.8 & .. & 61 & $63.8(2014)$ \\
\hline Mayotte (2010) & 17.3 & 18.1 & 16.5 & .. & .. & .. & .. \\
\hline Mozambique & 17 & 16.3 & 17.6 & 7.2 & 18.9 (2011 est.) & 289 & $27.1(2015)$ \\
\hline Reunion (2006) & 26.9 & 25.7 & 28.1 & .. & .. &.. &.. \\
\hline Rwanda & 19.7 & 18.9 & 20.4 & 5.8 & 23 (2014/15 est.) & 248 & $53.2(2014 / 15)$ \\
\hline Seychelles & 36.8 & 36.3 & 37.4 & 14 & .. &.. & .. \\
\hline Somalia & 18.5 & 18.7 & 18.3 & 8.3 & .. & 829 & .. \\
\hline South Sudan & 18.6 & 18.9 & 18.3 & $6.6(2014)$ & .. & 1150 & $4(2010)$ \\
\hline Tanzania & 18.2 & 17.9 & 18.4 & 8.4 & 19.8 (2015/16 est.) & 524 & $38.4(2015 / 16)$ \\
\hline Uganda & 15.7 & 14.9 & 16.5 & 5.3 & 18.9 (2011 est.) & 375 & $41.8(2018)$ \\
\hline Zambia & 16.9 & 16.7 & 17 & 8.1 & 19.2 (2013/14 est.) & 213 & $49(2013 / 14)$ \\
\hline Zimbabwe & 20.5 & 20.3 & 20.6 & 15.5 & 20 (2015 est.) & 458 & $66.8(2015)$ \\
\hline Angola & 15.9 & 15.4 & 16.4 & 8.2 & 19.4 (2015/16 est.) & 241 & $13.7(2015 / 16)$ \\
\hline Cameroon & 18.5 & 18.2 & 18.8 & 11.4 & 19.7 (2011 est.) & 529 & $34.4(2014)$ \\
\hline Central African Rep. & 20 & 19.7 & 20.3 & 7.5 & .. & 829 & $15.2(2010 / 11)$ \\
\hline Chad & 16.1 & 15.6 & 16.5 & 6.1 & 17.9 (2014/15 est.) & 1140 & $5.7(2014 / 15)$ \\
\hline Congo, Rep. & 19.5 & 19.3 & 19.7 & 9.6 & 19.8 (2011/12 est.) & 378 & $30.1(2014 / 15)$ \\
\hline Congo (D.R.) & 16.7 & 16.5 & 16.8 & 6.7 & 19.9 (2013/14 est.) & 473 & $20.4(2013 / 14)$ \\
\hline Equatorial Guinea & 20.3 & 19.9 & 20.7 & 8 & .. & 301 & $12.6(2011)$ \\
\hline Gabon & 21 & 21.4 & 20.6 & 15 & 20.3 (2012 est.) & 252 & $31.1(2012)$ \\
\hline Sao Tome \& Principe & 19.3 & 18.9 & 19.7 & 12.4 & 19.4 (2008/09 est.) & 130 & $40.6(2014)$ \\
\hline Algeria & 28.9 & 28.6 & 29.3 & 27.4 &.. & 112 & $57.1(2012 / 13)$ \\
\hline Egypt & 24.1 & 23.8 & 24.5 & 32 & 22.7 (2014 est.) & 37 & $58.5(2014)$ \\
\hline Libya & 25.8 & 25.9 & 25.7 & 32.5 &.. & 72 & $27.7(2014)$ \\
\hline Morocco & 29.1 & 28.7 & 29.6 & 26.1 & .. & 70 & 70.8 (2018) \\
\hline
\end{tabular}


Continued

\begin{tabular}{|c|c|c|c|c|c|c|c|}
\hline Sudan & 18.3 & 18.1 & 18.5 & $6.6(2014)$ & .. & 295 & $12.2(2014)$ \\
\hline Tunisia & 32.7 & 32 & 33.3 & 26.9 & .. & 43 & $62.5(2011 / 12)$ \\
\hline Western Sahara & 21.8 & 21.4 & 22.3 & .. & .. &.. & .. \\
\hline Botswana & 25.7 & 24.5 & 26.7 & 18.9 & .. & 144 & .. \\
\hline Lesotho & 24.7 & 24.7 & 24.7 & 16.6 & 21 (2014 est.) & 544 & $60.2(2014)$ \\
\hline Namibia & 21.8 & 21.1 & 22.6 & 17.2 & 21.5 (2013 est.) & 195 & $56.1(2013)$ \\
\hline South Africa & 28 & 27.9 & 28.1 & 28.3 & .. & 119 & $54.6(2016)$ \\
\hline eSwatini & 23.7 & 22.5 & 24.7 & 16.5 & .. & 437 & $66.1(2014)$ \\
\hline Benin & 17 & 16.4 & 17.6 & 9.6 & 20.4 (2017/18 est.) & 397 & $15.5(2017 / 18)$ \\
\hline Burkina Faso & 17.9 & 17 & 18.7 & 5.6 & 19.4 (2010 est.) & 320 & $31.7(2017 / 18)$ \\
\hline Cabo Verde & 26.8 & 25.9 & 27.6 & 11.8 & & .. & .. \\
\hline Cote d'Ivoire & 20.3 & 20.3 & 20.3 & 10.3 & 19.8 (2011/12 est.) & 617 & $23.3(2018)$ \\
\hline Gambia & 21.8 & 21.5 & 22.2 & 10.3 & 20.9 (2013 est.) & 597 & $9(2013)$ \\
\hline Ghana & 21.4 & 21 & 21.9 & 10.9 & 22.3 (2017 est.) & 308 & 30.8 (2017) \\
\hline Guinea & 19.1 & 18.9 & 19.4 & 7.7 & 19.5 (2018 est.) & 576 & $8.7(2016)$ \\
\hline Guinea-Bissau & 18 & 17.4 & 18.6 & 9.5 & .. & 667 & $16(2014)$ \\
\hline Liberia & 18 & 17.7 & 18.2 & 9.9 & 19.2 (2013 est.) & 661 & $31.2(2016)$ \\
\hline Mali & 16 & 15.3 & 16.7 & 8.6 & 18.9 (2018 est.) & 562 & $15.6(2015)$ \\
\hline Mauritania & 21 & 20.1 & 22 & 12.7 & .. & 766 & $17.8(2015)$ \\
\hline Niger & 14.8 & 14.5 & 15.1 & 5.5 & 18.1 (2012 est.) & 509 & $11(2018)$ \\
\hline Nigeria & 18.6 & 18.4 & 18.9 & 8.9 & 20.3 (2013 est.) & 917 & $27.6(2018)$ \\
\hline Saint Helena & 43.2 & 43.2 & 43.3 & .. & &.. & .. \\
\hline Senegal & 19.4 & 18.5 & 20.3 & 8.8 & 21.9 (2017 est.) & 315 & $27.8(2017)$ \\
\hline Sierra Leone & 19.1 & 18.5 & 19.7 & 8.7 & 19.2 (2013 est.) & 1120 & $22.5(2017)$ \\
\hline Togo & 20 & 19.7 & 20.3 & 8.4 & 21 (2013/14 est.) & 396 & $19.9(2013 / 14)$ \\
\hline Average & & & & & & 436.4 & \\
\hline
\end{tabular}

(b)

\begin{tabular}{cccccccc}
\hline Eastern Africa & $\begin{array}{c}\text { Median age } \\
\text { Total }\end{array}$ & Male & Female & $\begin{array}{c}\text { Obesity } \\
\text { Pre. Rate \% }\end{array}$ & $\begin{array}{c}\text { Mother's mean } \\
\text { age at first birth }\end{array}$ & $\begin{array}{c}\text { Maternal Mortality } \\
\text { Rates per 100,000 }\end{array}$ & $\begin{array}{c}\text { Contraceptive } \\
\text { Preve. Use \% }\end{array}$ \\
\hline Burundi & 17.7 & 17.4 & 18 & 5.4 & $21.3(2010$ est.) & 548 & $28.5(2016 / 17)$ \\
Comoros & 20.9 & 20.2 & 21.5 & 7.8 & $24.6(2012$ est.) & 273 & $19.4(2012)$ \\
Djibouti & 24.9 & 23 & 26.4 & 13.5 & & 248 & $19(2012)$ \\
Eritrea & 20.3 & 19.7 & 20.8 & 5 & $21.3(2010$ est.) & 480 & $8.4(2010)$ \\
Ethiopia & 19.8 & 19.6 & 20.1 & 4.5 & $20(2016$ est.) & 401 & $40.1(2018)$ \\
Kenya & 20 & 19.9 & 20.1 & 7.1 & $20.3(2014$ est.) & 342 & $60.5(2017)$ \\
Madagascar & 20.3 & 20.1 & 20.5 & 5.3 & $19.5(2008 / 09$ est.) & 335 & $47.9(2017)$ \\
Malawi & 16.8 & 16.7 & 16.9 & 5.8 & $18.9(2015 / 16$ est.) & 349 & $59.2(2015 / 16)$ \\
\hline
\end{tabular}




\section{Continued}

\begin{tabular}{|c|c|c|c|c|c|c|c|}
\hline Mauritius & 36.3 & 35 & 37.6 & 10.8 & .. & 61 & $63.8(2014)$ \\
\hline Mayotte (2010) & 17.3 & 18.1 & 16.5 & .. & .. & .. & .. \\
\hline Mozambique & 17 & 16.3 & 17.6 & 7.2 & 18.9 (2011 est.) & 289 & $27.1(2015)$ \\
\hline Reunion (2006) & 26.9 & 25.7 & 28.1 & .. & .. & .. & .. \\
\hline Rwanda & 19.7 & 18.9 & 20.4 & 5.8 & 23 (2014/15 est.) & 248 & $53.2(2014 / 15)$ \\
\hline Seychelles & 36.8 & 36.3 & 37.4 & 14 & .. & .. & .. \\
\hline Somalia & 18.5 & 18.7 & 18.3 & 8.3 & .. & 829 & .. \\
\hline South Sudan & 18.6 & 18.9 & 18.3 & $6.6(2014)$ & .. & 1150 & $4(2010)$ \\
\hline Tanzania & 18.2 & 17.9 & 18.4 & 8.4 & 19.8 (2015/16 est.) & 524 & $38.4(2015 / 16)$ \\
\hline Uganda & 15.7 & 14.9 & 16.5 & 5.3 & 18.9 (2011 est.) & 375 & $41.8(2018)$ \\
\hline Zambia & 16.9 & 16.7 & 17 & 8.1 & 19.2 (2013/14 est.) & 213 & $49(2013 / 14)$ \\
\hline Zimbabwe & 20.5 & 20.3 & 20.6 & 15.5 & 20 (2015 est.) & 458 & $66.8(2015)$ \\
\hline Average & & & & & & 420.1 & \\
\hline
\end{tabular}

(c)

\begin{tabular}{|c|c|c|c|c|c|c|c|}
\hline Middle Africa & $\begin{array}{l}\text { Median age } \\
\text { Total }\end{array}$ & Male & Female & $\begin{array}{c}\text { Obesity } \\
\text { Pre. Rate \% }\end{array}$ & $\begin{array}{l}\text { Mother's mean } \\
\text { age at first birth }\end{array}$ & $\begin{array}{l}\text { Maternal Mortality } \\
\text { Rates per } 100,000\end{array}$ & $\begin{array}{l}\text { Contraceptive } \\
\text { Preve. Use \% }\end{array}$ \\
\hline Angola & 15.9 & 15.4 & 16.4 & 8.2 & 19.4 (2015/16 est.) & 241 & $13.7(2015 / 16)$ \\
\hline Cameroon & 18.5 & 18.2 & 18.8 & 11.4 & 19.7 (2011 est.) & 529 & $34.4(2014)$ \\
\hline Central African Rep. & 20 & 19.7 & 20.3 & 7.5 & .. & 829 & $15.2(2010 / 11)$ \\
\hline Chad & 16.1 & 15.6 & 16.5 & 6.1 & 17.9 (2014/15 est.) & 1140 & $5.7(2014 / 15)$ \\
\hline Congo, Rep. & 19.5 & 19.3 & 19.7 & 9.6 & 19.8 (2011/12 est.) & 378 & $30.1(2014 / 15)$ \\
\hline Congo (D.R.) & 16.7 & 16.5 & 16.8 & 6.7 & 19.9 (2013/14 est.) & 473 & $20.4(2013 / 14)$ \\
\hline Equatorial Guinea & 20.3 & 19.9 & 20.7 & 8 & .. & 301 & $12.6(2011)$ \\
\hline Gabon & 21 & 21.4 & 20.6 & 15 & 20.3 (2012 est.) & 252 & $31.1(2012)$ \\
\hline Sao Tome \& Principe & 19.3 & 18.9 & 19.7 & 12.4 & 19.4 (2008/09 est.) & 130 & $40.6(2014)$ \\
\hline Average & & & & & & 474.8 & \\
\hline
\end{tabular}

(d)

\begin{tabular}{|c|c|c|c|c|c|c|c|}
\hline Northern Africa & $\begin{array}{l}\text { Median age } \\
\text { Total }\end{array}$ & Male & Female & $\begin{array}{c}\text { Obesity } \\
\text { Pre. Rate \% }\end{array}$ & $\begin{array}{l}\text { Mother's mean } \\
\text { age at first birth }\end{array}$ & $\begin{array}{l}\text { Maternal Mortality } \\
\text { Rates per } 100,000\end{array}$ & $\begin{array}{c}\text { Contraceptive } \\
\text { Preve. Use \% }\end{array}$ \\
\hline Algeria & 28.9 & 28.6 & 29.3 & 27.4 & 22.7 (2014 est.) & 112 & $58.5(2014)$ \\
\hline Egypt & 24.1 & 23.8 & 24.5 & 32 & .. & 37 & $27.7(2014)$ \\
\hline Libya & 25.8 & 25.9 & 25.7 & 32.5 & .. & 72 & 70.8 (2018) \\
\hline Morocco & 29.1 & 28.7 & 29.6 & 26.1 & .. & 70 & $12.2(2014)$ \\
\hline Sudan & 18.3 & 18.1 & 18.5 & $6.6(2014)$ & .. & 295 & $62.5(2011 / 12)$ \\
\hline Tunisia & 32.7 & 32 & 33.3 & 26.9 & .. & 43 &.. \\
\hline Western Sahara & 21.8 & 21.4 & 22.3 & .. & .. & .. &.. \\
\hline Average & & & & & & 104.8 & \\
\hline
\end{tabular}


(e)

\begin{tabular}{cccccccc}
\hline Southern Africa & $\begin{array}{c}\text { Median age } \\
\text { Total }\end{array}$ & Male & Female & $\begin{array}{c}\text { Obesity } \\
\text { Pre. Rate \% }\end{array}$ & $\begin{array}{c}\text { Mother's mean } \\
\text { age at first birth }\end{array}$ & $\begin{array}{c}\text { Maternal Mortality } \\
\text { Rates per 100,000 }\end{array}$ & $\begin{array}{c}\text { Contraceptive } \\
\text { Preve. Use \% }\end{array}$ \\
\hline Botswana & 25.7 & 24.5 & 26.7 & 18.9 &.. & 144 &.. \\
Lesotho & 24.7 & 24.7 & 24.7 & 16.6 & $21(2014$ est.) & 544 & $60.2(2014)$ \\
Namibia & 21.8 & 21.1 & 22.6 & 17.2 & $21.5(2013$ est.) & 195 & $56.1(2013)$ \\
South Africa & 28 & 27.9 & 28.1 & 28.3 &.. & 119 & $54.6(2016)$ \\
eSwatini & 23.7 & 22.5 & 24.7 & 16.5 &.. & 437 & $66.1(2014)$ \\
Average & & & & & & 287.8 & \\
\hline
\end{tabular}

(f)

\begin{tabular}{|c|c|c|c|c|c|c|c|}
\hline Western Africa & $\begin{array}{l}\text { Median age } \\
\text { Total }\end{array}$ & Male & Female & $\begin{array}{c}\text { Obesity } \\
\text { Pre. Rate \% }\end{array}$ & $\begin{array}{l}\text { Mother's mean } \\
\text { age at first birth }\end{array}$ & $\begin{array}{l}\text { Maternal Mortality } \\
\text { Rates per } 100,000\end{array}$ & $\begin{array}{c}\text { Contraceptive } \\
\text { Preve. Use \% }\end{array}$ \\
\hline Benin & 17 & 16.4 & 17.6 & 9.6 & 20.4 (2017/18 est.) & 397 & $15.5(2017 / 18)$ \\
\hline Burkina Faso & 17.9 & 17 & 18.7 & 5.6 & 19.4 (2010 est.) & 320 & $31.7(2017 / 18)$ \\
\hline Cabo Verde & 26.8 & 25.9 & 27.6 & 11.8 & & .. & .. \\
\hline Cote d'Ivoire & 20.3 & 20.3 & 20.3 & 10.3 & 19.8 (2011/12 est.) & 617 & $23.3(2018)$ \\
\hline Gambia & 21.8 & 21.5 & 22.2 & 10.3 & 20.9 (2013 est.) & 597 & $9(2013)$ \\
\hline Ghana & 21.4 & 21 & 21.9 & 10.9 & 22.3 (2017 est.) & 308 & $30.8(2017)$ \\
\hline Guinea & 19.1 & 18.9 & 19.4 & 7.7 & 19.5 (2018 est.) & 576 & $8.7(2016)$ \\
\hline Guinea-Bissau & 18 & 17.4 & 18.6 & 9.5 & .. & 667 & $16(2014)$ \\
\hline Liberia & 18 & 17.7 & 18.2 & 9.9 & 19.2 (2013 est.) & 661 & $31.2(2016)$ \\
\hline Mali & 16 & 15.3 & 16.7 & 8.6 & 18.9 (2018 est.) & 562 & $15.6(2015)$ \\
\hline Mauritania & 21 & 20.1 & 22 & 12.7 & .. & 766 & $17.8(2015)$ \\
\hline Niger & 14.8 & 14.5 & 15.1 & 5.5 & 18.1 (2012 est.) & 509 & $11(2018)$ \\
\hline Nigeria & 18.6 & 18.4 & 18.9 & 8.9 & 20.3 (2013 est.) & 917 & $27.6(2018)$ \\
\hline Saint Helena & 43.2 & 43.2 & 43.3 & .. & & .. & .. \\
\hline Senegal & 19.4 & 18.5 & 20.3 & 8.8 & 21.9 (2017 est.) & 315 & 27.8 (2017) \\
\hline Sierra Leone & 19.1 & 18.5 & 19.7 & 8.7 & 19.2 (2013 est.) & 1120 & 22.5 (2017) \\
\hline Togo & 20 & 19.7 & 20.3 & 8.4 & 21 (2013/14 est.) & 396 & $19.9(2013 / 14)$ \\
\hline Average & & & & & & 581.9 & \\
\hline
\end{tabular}

Source: Source: Compiled and computed based on data in the 2020 CIA World Factbook (https://www.cia.gov/library/publications/the-world-factbook/). Note: Data for Mayotte are from the 2010 World Factbook and Reunion from the 2006 World Factbook. France has combined the data for these two nations with the population of France. 
Table A4. Population, GDP, GDP Per Capita, School Life Expectancy, and Education Expenditures, Percent Urban Population, and Urbanization Rate.

(a)

\begin{tabular}{|c|c|c|c|c|c|c|c|c|c|c|c|c|}
\hline Africa & $\begin{array}{c}\text { Population } \\
\text { (2017 est.) }\end{array}$ & $\begin{array}{l}\text { GDP (PPP) } \\
\text { US\$ Billion } \\
\text { (2017 est.) }\end{array}$ & $\begin{array}{l}\text { GDP per } \\
\text { capita } \\
\text { US\$ } \\
\text { (2017 est.) }\end{array}$ & $\begin{array}{l}\text { School life } \\
\text { expectancy }\end{array}$ & Male & Female & $\begin{array}{c}\text { Literacy } \\
\text { rate } \\
15 \& \\
\text { over } \%\end{array}$ & Male & Female & $\begin{array}{l}\text { Education } \\
\text { expenditures } \\
\% \text { of GDP }\end{array}$ & $\begin{array}{c}\text { Urban } \\
\text { population } \\
\%(2020)\end{array}$ & $\begin{array}{l}\text { Urbanization } \\
\text { rate } \% \\
(2015-2020)\end{array}$ \\
\hline Burundi & $10,954,718$ & 8.007 & 700 & $11(2017)$ & 11 & 11 & $68.4(2017)$ & 76.3 & 61.2 & $4.8(2017$ & 13.7 & 5.68 \\
\hline Comoros & 808,080 & 1.319 & 1600 & $11(2014)$ & 11 & 11 & $58.8(2018)$ & 64.6 & 53 & $2.5(2015)$ & 29.4 & 2.87 \\
\hline Djibouti & 865,267 & 3.64 & 3600 & $6(2011)$ & 7 & 6 &.. & .. & .. & $4.5(2010)$ & 78.1 & 1.67 \\
\hline Eritrea & $5,918,919$ & 9.402 & 1600 & $5(2015)$ & 6 & 5 & $76.6(2018)$ & 84.4 & 68.9 & .. & 41.3 & 3.86 \\
\hline Ethiopia & $99,964,615$ & 200.6 & 2200 & $8(2012)$ & 9 & 8 & $51.8(2017)$ & 57.2 & 44.4 & $4.7(2015)$ & 21.7 & 4.63 \\
\hline Kenya & $50,048,729$ & 163.7 & 3500 & 11 (2009) & 11 & 11 & $81.5(2018)$ & 85 & 78.2 & $5.2(2017)$ & 28 & 4.23 \\
\hline Madagascar & $25,054,161$ & 39.85 & 1600 & $10(2016)$ & 10 & 10 & 74.8 (2018) & 77.3 & 72.4 & 2.8 (2014) & 38.5 & 4.48 \\
\hline Malawi & $19,196,246$ & 22.42 & 1200 & $11(2011)$ & 11 & 11 & $62.1(2015)$ & 69.8 & 55.2 & $4(2017)$ & 17.4 & 4.19 \\
\hline Mauritius & $1,356,388$ & 28.27 & 22,300 & 15 (2017) & 14 & 16 & $91.3(2018)$ & 91.3 & 93.4 & $4.8(2018)$ & 40.8 & 0.11 \\
\hline $\begin{array}{l}\text { Mayotte } \\
(2010)\end{array}$ & 231,139 & 0.954 & 4900 &.. &.. &.. &.. &.. &.. & & .. &.. \\
\hline Mozambique & $27,809,441$ & 37.09 & 1300 & $10(2017)$ & 10 & 9 & $60.7(2017)$ & 72.6 & 50.3 & $6.5(2013)$ & 37.1 & 4.35 \\
\hline $\begin{array}{c}\text { Reunion } \\
(2006)\end{array}$ & 787,584 & 4.79 & 6200 &.. &.. &.. &.. &.. &.. & &.. &.. \\
\hline Rwanda & $11,901,484$ & 24.68 & 2100 & $11(2017)$ & 11 & 11 & $73.2(2018)$ & 77.6 & 69.4 & $3.1(2018)$ & 17.4 & 2.86 \\
\hline Seychelles & 93,920 & 2.75 & 29,300 & $16(2016)$ & 15 & 16 & $95.9(2018)$ & 95.4 & 96.4 & $4.4(2016)$ & 57.5 & 1.26 \\
\hline Somalia & $11,031,386$ & 20.44 & .. & .. & .. & .. & .. & .. & .. & .. & 46.1 & 4.23 \\
\hline South Sudan & $10,507,520$ & 20.01 & 1600 & .. & .. & .. & $34.5(2018)$ & 40.3 & 28.9 & $1(2017)$ & 20.2 & 4.1 \\
\hline Tanzania & $53,950,935$ & 162.5 & 3200 & $8(2013)$ & 8 & 8 & $77.9(2015)$ & 83.2 & 73.1 & 3.4 (2014) & 35.2 & 5.22 \\
\hline Uganda & $39,185,957$ & 89.19 & 2400 & $10(2011)$ & 10 & 10 & $76.5(2018)$ & 82.7 & 70.8 & $2.6(2017)$ & 25 & 5.7 \\
\hline Zambia & $15,972,000$ & 68.93 & 4000 & .. & .. & .. & 86.7 & 90.6 & 83.1 & .. & 44.6 & 4.23 \\
\hline Zimbabwe & $13,805,084$ & 34.27 & 2300 & $10(2013)$ & 10 & 10 & 86.5 (2015) & 88.5 & 84.6 & 6.1 (2014) & 32.2 & 2.19 \\
\hline Angola & $29,310,273$ & 193.6 & 6800 & $10(2011)$ & 13 & 8 & $71.1(2015)$ & 82 & 60.7 & $3.4(2010)$ & 66.8 & 4.32 \\
\hline Cameroon & $25,556,287$ & 89.54 & 3700 & $13(2016)$ & 14 & 12 & $77.1(2018)$ & 82.6 & 71.6 & $3.1(2017)$ & 57.6 & 3.63 \\
\hline $\begin{array}{c}\text { Central } \\
\text { African Rep. }\end{array}$ & $5,625,118$ & 3.39 & 700 & 7 (2012) & 8 & 6 & $37.4(2018)$ & 49.5 & 25.8 & $1.2(2011)$ & 42.2 & 2.52 \\
\hline Chad & $15,327,016$ & 28.62 & 2300 & $8(2014)$ & 9 & 6 & $22.3(2016)$ & 31.3 & 14 & $2.9(2013)$ & 23.5 & 3.88 \\
\hline Congo, Rep. & $4,954,674$ & 29.39 & 6800 & $11(2012)$ & 11 & 11 & $80.3(2018)$ & 86.1 & 74.6 & 4.6 (2015) & 67.8 & 3.28 \\
\hline Congo (D.R.) & $92,459,200$ & 68.6 & 800 & $10(2013)$ & 11 & 9 & 77 (2016) & 88.5 & 66.5 & $1.5(2017)$ & 45.6 & 4.53 \\
\hline $\begin{array}{c}\text { Equatorial } \\
\text { Guinea }\end{array}$ & 778,358 & 31.52 & 37,400 & .. & .. & .. & $95.3(2015)$ & 97.4 & 93 & .. & 73.1 & 4.28 \\
\hline Gabon & $2,060,381$ & 36.66 & 18,100 & .. & .. & .. & 84.7 (2018) & 85.9 & 83.4 & $2.7(2014)$ & 90.1 & 2.61 \\
\hline $\begin{array}{l}\text { Sao Tome \& } \\
\text { Principe }\end{array}$ & 201,025 & 0.686 & 3200 & $12(2015)$ & 12 & 13 & $92.8(2018)$ & 96.2 & 89.5 & 4.9 (2017) & 74.4 & 3.33 \\
\hline Algeria & $40,969,443$ & 630 & 15,200 & $14(2011)$ & 14 & 15 & $81.4(2018)$ & 87.4 & 75.3 & .. & 73.7 & 2.46 \\
\hline
\end{tabular}




\section{Continued}

\begin{tabular}{|c|c|c|c|c|c|c|c|c|c|c|c|c|}
\hline Egypt & $97,041,072$ & 1,204 & 12,700 & $13(2016)$ & 13 & 13 & $71.2(2017)$ & 76.5 & 65.5 & .. & 42.8 & 1.86 \\
\hline Libya & $6,483,018$ & 61.97 & 9600 & .. &.. &.. & $91(2015)$ & 96.7 & 85.6 & .. & 80.7 & 1.68 \\
\hline Morocco & $34,513,849$ & 298.6 & 8600 & $13(2017)$ & 14 & 13 & $73.8(2018)$ & 83.3 & 64.6 & $5.3(2009)$ & 63.5 & 2.14 \\
\hline Sudan & $41,824,518$ & 177.4 & 4300 & $8(2015)$ & 8 & 7 & 60.7 (2018) & 65.4 & 56.1 & $2.2(2009)$ & 35.3 & 3.17 \\
\hline Tunisia & $11,403,800$ & 137.7 & 11,900 & 15 (2016) & 14 & 16 & $81.8(2015)$ & 89.6 & 74.2 & $6.6(2015)$ & 69.6 & 1.53 \\
\hline $\begin{array}{l}\text { Western } \\
\text { Sahara }\end{array}$ & 603,253 & 0.907 & 2500 & .. &.. &.. & .. & .. & .. & .. & 86.8 & 2.61 \\
\hline Botswana & $2,214,858$ & 39.01 & 17,000 & $13(2013)$ & 13 & 13 & $88.5(2015)$ & 88 & 88.9 & $9.6(2009)$ & 70.9 & 2.87 \\
\hline Lesotho & $1,958,042$ & 6.656 & 3300 & $11(2015)$ & 10 & 11 & $79.4(2015)$ & 70.1 & 88.3 & $6.4(2018)$ & 29 & 2.83 \\
\hline Namibia & $2,484,780$ & 26.6 & 11,200 & .. & .. &.. & $91.5(2018)$ & 91.6 & 91.4 & $3.1(2014)$ & 52 & 4.2 \\
\hline South Africa & $54,841,552$ & 767.2 & 13,600 & $14(2016)$ & 13 & 14 & 87 (2017) & 87.7 & 86.5 & $6.2(2018)$ & 67.4 & 1.97 \\
\hline eSwatini & $1,078,215$ & 11.6 & 10,100 & $11(2013)$ & 12 & 11 & $88.4(2015)$ & 88.3 & 88.5 & $7.1(2014)$ & 24.2 & 2.46 \\
\hline Benin & $11,612,983$ & 25.39 & 2300 & 13 (2016) & 14 & 11 & $42.4(2018)$ & 54 & 31.1 & $4(2016)$ & 48.4 & 3.89 \\
\hline Burkina Faso & $19,199,732$ & 35.85 & 1900 & $9(2017)$ & 9 & 9 & $41.2(2018)$ & 50.1 & 32.7 & $4.2(2015)$ & 30.6 & 4.99 \\
\hline Cabo Verde & 560,899 & 3.777 & 7000 & $12(2017)$ & 12 & 12 & $86.8(2015)$ & 91.7 & 82 & $5.2(2017)$ & 66.7 & 1.97 \\
\hline Cote d'Ivoire & $25,659,816$ & 97.16 & 3900 & $10(2016)$ & 11 & 9 & $47.2(2018)$ & 53.7 & 40.5 & $5.1(2017)$ & 51.7 & 3.38 \\
\hline Gambia & $2,051,363$ & 5.556 & 2600 & $9(2010)$ & 9 & 9 & $50.8(2015)$ & 61.8 & 41.6 & $2.1(2016)$ & 62.6 & 4.07 \\
\hline Ghana & $27,499,924$ & 134 & 4700 & $12(2017)$ & 12 & 11 & $76.6(2015)$ & 82 & 71.4 & $3.6(2017)$ & 57.3 & 3.34 \\
\hline Guinea & $11,534,306$ & 27.97 & 2200 & $9(2014)$ & 10 & 8 & $30.4(2015)$ & 38.1 & 22.8 & $2.2(2017)$ & 36.5 & 3.54 \\
\hline Liberia & $4,689,021$ & 6.112 & 1300 & .. & .. & .. & 48.3 (2017) & 62.7 & 34.1 & $3.8(2017)$ & 52.1 & 3.41 \\
\hline Mali & $17,885,245$ & 41.22 & 2200 & $7(2015)$ & 8 & 7 & 35.5 (2018) & 46.2 & 25.7 & $3.1(2016)$ & 43.9 & 4.86 \\
\hline Mauritania & $3,758,571$ & 17.28 & 4500 & $8(2017)$ & 8 & 8 & $53.5(2017)$ & 63.7 & 43.4 & $2.6(2016)$ & 55.3 & 4.28 \\
\hline Niger & $20,391,729$ & 21.86 & 1200 & $6(2017)$ & 7 & 6 & $19.1(2015)$ & 27.3 & 11 & 3.5 (2017) & 16.6 & 4.27 \\
\hline Nigeria & $198,346,055$ & 1,121 & 5900 & $9(2011)$ & 9 & 8 & $62(2018)$ & 71.3 & 52.7 & .. & 52 & 4.23 \\
\hline Saint Helena & 7828 & 0.0311 & 7800 & .. & .. & .. & .. & .. & .. & .. & 40.1 & 0.73 \\
\hline Senegal & $14,668,522$ & 54.8 & 3500 & $9(2015)$ & 9 & 9 & $51.9(2017)$ & 64.8 & 39.8 & $4.8(2017)$ & 48.1 & 3.73 \\
\hline Sierra Leone & $6,163,195$ & 11.55 & 1600 & .. & .. &.. & $43.2(2018)$ & 51.6 & 39.8 & $4.6(2017)$ & 42.9 & 3.12 \\
\hline Togo & $7,965,055$ & 12.97 & 1700 & 13 (2017) & 14 & 11 & $63.7(2015)$ & 77.3 & 51.2 & $5(2016)$ & 42.8 & 3.76 \\
\hline Total/Ave. & $\begin{array}{c}1,244,915,1 \\
59\end{array}$ & 5518.6 & 4433 & & & & & & & & & \\
\hline
\end{tabular}

(b)

\begin{tabular}{|c|c|c|c|c|c|c|c|c|c|c|c|c|}
\hline $\begin{array}{c}\text { Eastern } \\
\text { Africa }\end{array}$ & $\begin{array}{l}\text { Population } \\
\text { (2017 est.) }\end{array}$ & $\begin{array}{l}\text { GDP (PPP) } \\
\text { US\$ Billion } \\
\text { (2017 est.) }\end{array}$ & $\begin{array}{l}\text { GDP per } \\
\text { capita } \\
\text { US\$ } \\
\text { (2017 est.) }\end{array}$ & $\begin{array}{l}\text { School life } \\
\text { expectancy }\end{array}$ & Male & Female & $\begin{array}{c}\text { Literacy } \\
\text { rate } \\
15 \& \\
\text { over } \%\end{array}$ & Male & Female & $\begin{array}{l}\text { Education } \\
\text { expenditures } \\
\% \text { of GDP }\end{array}$ & $\begin{array}{c}\text { Urban } \\
\text { population } \\
\%(2020)\end{array}$ & $\begin{array}{c}\text { Urbanization } \\
\text { rate } \% \\
(2015-2020)\end{array}$ \\
\hline Burundi & $10,954,718$ & 8.007 & 700 & $11(2017)$ & 11 & 11 & $68.4(2017)$ & 76.3 & 61.2 & $4.8(2017$ & 13.7 & 5.68 \\
\hline Comoros & 808,080 & 1.319 & 1600 & $11(2014)$ & 11 & 11 & $58.8(2018)$ & 64.6 & 53 & $2.5(2015)$ & 29.4 & 2.87 \\
\hline
\end{tabular}


Continued

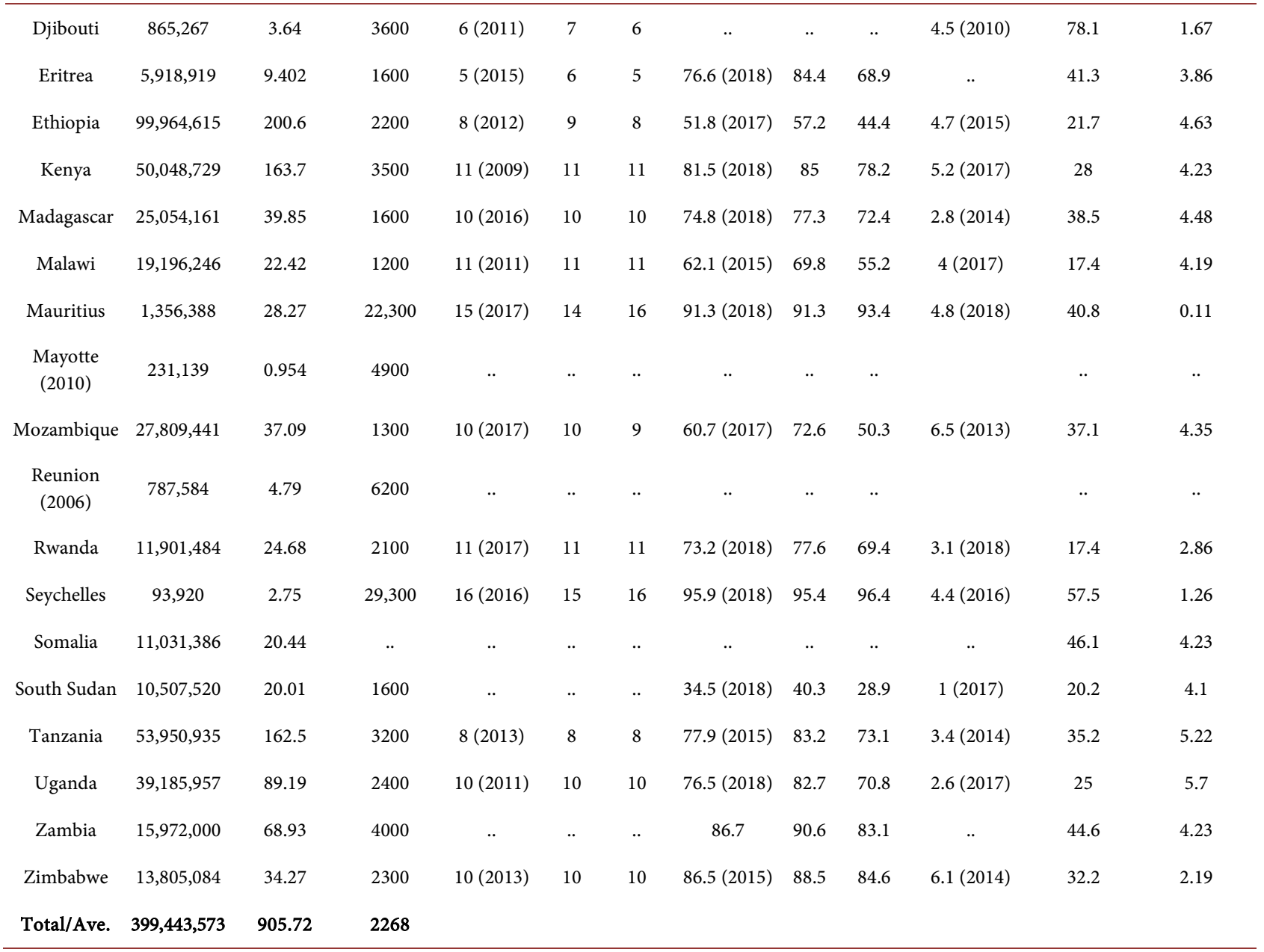

(c)

\begin{tabular}{|c|c|c|c|c|c|c|c|c|c|c|c|c|}
\hline $\begin{array}{c}\text { Middle } \\
\text { Africa }\end{array}$ & $\begin{array}{l}\text { Population } \\
\text { (2017 est.) }\end{array}$ & $\begin{array}{l}\text { GDP (PPP) } \\
\text { US\$ Billion } \\
\text { (2017 est.) }\end{array}$ & $\begin{array}{c}\text { GDP per } \\
\text { capita } \\
\text { US\$ } \\
\text { (2017 est.) }\end{array}$ & $\begin{array}{l}\text { School life } \\
\text { expectancy }\end{array}$ & Male & Female & $\begin{array}{c}\text { Literacy } \\
\text { rate } \\
15 \& \\
\text { over } \%\end{array}$ & Male & Female & $\begin{array}{l}\text { Education } \\
\text { expenditures } \\
\% \text { of GDP }\end{array}$ & $\begin{array}{c}\text { Urban } \\
\text { population } \\
\%(2020)\end{array}$ & $\begin{array}{c}\text { Urbanization } \\
\text { rate } \% \\
(2015-2020)\end{array}$ \\
\hline Angola & $29,310,273$ & 193.6 & 6800 & $10(2011)$ & 13 & 8 & $71.1(2015)$ & 82 & 60.7 & $3.4(2010)$ & 66.8 & 4.32 \\
\hline Cameroon & $25,556,287$ & 89.54 & 3700 & $13(2016)$ & 14 & 12 & 77.1 (2018) & 82.6 & 71.6 & $3.1(2017)$ & 57.6 & 3.63 \\
\hline $\begin{array}{c}\text { Central } \\
\text { African Rep. }\end{array}$ & $5,625,118$ & 3.39 & 700 & $7(2012)$ & 8 & 6 & $37.4(2018)$ & 49.5 & 25.8 & $1.2(2011)$ & 42.2 & 2.52 \\
\hline Chad & $15,327,016$ & 28.62 & 2300 & $8(2014)$ & 9 & 6 & $22.3(2016)$ & 31.3 & 14 & $2.9(2013)$ & 23.5 & 3.88 \\
\hline Congo, Rep. & $4,954,674$ & 29.39 & 6800 & $11(2012)$ & 11 & 11 & 80.3 (2018) & 86.1 & 74.6 & $4.6(2015)$ & 67.8 & 3.28 \\
\hline Congo (D.R.) & $92,459,200$ & 68.6 & 800 & $10(2013)$ & 11 & 9 & 77 (2016) & 88.5 & 66.5 & $1.5(2017)$ & 45.6 & 4.53 \\
\hline Gabon & $2,060,381$ & 36.66 & 18,100 & .. & .. & .. & 84.7 (2018) & 85.9 & 83.4 & $2.7(2014)$ & 90.1 & 2.61 \\
\hline $\begin{array}{c}\text { Sao Tome \& } \\
\text { Principe }\end{array}$ & 201,025 & 0.686 & 3200 & $12(2015)$ & 12 & 13 & $92.8(2018)$ & 96.2 & 89.5 & 4.9 (2017) & 74.4 & 3.33 \\
\hline Total/Ave. & $176,272,332$ & 450.486 & 2556 & & & & & & & & & \\
\hline
\end{tabular}


(d)

\begin{tabular}{|c|c|c|c|c|c|c|c|c|c|c|c|c|}
\hline $\begin{array}{l}\text { Northern } \\
\text { Africa }\end{array}$ & $\begin{array}{l}\text { Population } \\
\text { (2017 est.) }\end{array}$ & $\begin{array}{l}\text { GDP (PPP) } \\
\text { US\$ Billion } \\
\text { (2017 est.) }\end{array}$ & $\begin{array}{l}\text { GDP per } \\
\text { capita } \\
\text { US\$ } \\
\text { (2017 est.) }\end{array}$ & $\begin{array}{l}\text { School life } \\
\text { expectancy }\end{array}$ & Male & Female & $\begin{array}{c}\text { Literacy } \\
\text { rate } \\
15 \& \\
\text { over \% }\end{array}$ & Male & Female & $\begin{array}{l}\text { Education } \\
\text { expenditures } \\
\% \text { of GDP }\end{array}$ & $\begin{array}{c}\text { Urban } \\
\text { population } \\
\%(2020)\end{array}$ & $\begin{array}{l}\text { Urbanization } \\
\text { rate } \% \\
(2015-2020)\end{array}$ \\
\hline Algeria & $40,969,443$ & 630 & 15,200 & $14(2011)$ & 14 & 15 & $81.4(2018)$ & 87.4 & 75.3 &.. & 73.7 & 2.46 \\
\hline Egypt & $97,041,072$ & 1204 & 12,700 & $13(2016)$ & 13 & 13 & $71.2(2017)$ & 76.5 & 65.5 & .. & 42.8 & 1.86 \\
\hline Libya & $6,483,018$ & 61.97 & 9600 & .. &.. & .. & 91 (2015) & 96.7 & 85.6 & .. & 80.7 & 1.68 \\
\hline Morocco & $34,513,849$ & 298.6 & 8600 & 13 (2017) & 14 & 13 & 73.8 (2018) & 83.3 & 64.6 & 5.3 (2009) & 63.5 & 2.14 \\
\hline Sudan & $41,824,518$ & 177.4 & 4300 & 8 (2015) & 8 & 7 & $60.7(2018)$ & 65.4 & 56.1 & $2.2(2009)$ & 35.3 & 3.17 \\
\hline Tunisia & $11,403,800$ & 137.7 & 11,900 & 15 (2016) & 14 & 16 & 81.8 (2015) & 89.6 & 74.2 & $6.6(2015)$ & 69.6 & 1.53 \\
\hline $\begin{array}{l}\text { Western } \\
\text { Sahara }\end{array}$ & 603,253 & 0.907 & 2500 & .. & .. & .. & .. &.. & .. & .. & 86.8 & 2.61 \\
\hline Total/Ave. & $232,838,953$ & $1,703.177$ & 7315 & & & & & & & & & \\
\hline
\end{tabular}

(e)

\begin{tabular}{|c|c|c|c|c|c|c|c|c|c|c|c|c|}
\hline $\begin{array}{l}\text { Southern } \\
\text { Africa }\end{array}$ & $\begin{array}{l}\text { Population } \\
\text { (2017 est.) }\end{array}$ & $\begin{array}{l}\text { GDP (PPP) } \\
\text { US\$ Billion } \\
\text { (2017 est.) }\end{array}$ & $\begin{array}{l}\text { GDP per } \\
\text { capita } \\
\text { US\$ } \\
\text { (2017 est.) }\end{array}$ & $\begin{array}{l}\text { School life } \\
\text { expectancy }\end{array}$ & Male & Female & $\begin{array}{c}\text { Literacy } \\
\text { rate } \\
15 \& \\
\text { over } \%\end{array}$ & Male & Female & $\begin{array}{l}\text { Education } \\
\text { expenditures } \\
\% \text { of GDP }\end{array}$ & $\begin{array}{c}\text { Urban } \\
\text { population } \\
\%(2020)\end{array}$ & $\begin{array}{l}\text { Urbanization } \\
\text { rate } \% \\
(2015-2020)\end{array}$ \\
\hline Botswana & $2,214,858$ & 39.01 & 17,000 & $13(2013)$ & 13 & 13 & 88.5 (2015) & 88 & 88.9 & $9.6(2009)$ & 70.9 & 2.87 \\
\hline Lesotho & $1,958,042$ & 6.656 & 3300 & $11(2015)$ & 10 & 11 & $79.4(2015)$ & 70.1 & 88.3 & $6.4(2018)$ & 29 & 2.83 \\
\hline Namibia & $2,484,780$ & 26.6 & 11,200 &.. & .. & .. & 91.5 (2018) & 91.6 & 91.4 & $3.1(2014)$ & 52 & 4.2 \\
\hline South Africa & $54,841,552$ & 767.2 & 13,600 & 14 (2016) & 13 & 14 & 87 (2017) & 87.7 & 86.5 & $6.2(2018)$ & 67.4 & 1.97 \\
\hline eSwatini & $1,078,215$ & 11.6 & 10,100 & $11(2013)$ & 12 & 11 & 88.4 (2015) & 88.3 & 88.5 & $7.1(2014)$ & 24.2 & 2.46 \\
\hline Total/Ave. & $62,577,447$ & 851.066 & 13,600 & & & & & & & & & \\
\hline
\end{tabular}

(f)

\begin{tabular}{|c|c|c|c|c|c|c|c|c|c|c|c|c|}
\hline $\begin{array}{c}\text { Western } \\
\text { Africa }\end{array}$ & $\begin{array}{l}\text { Population } \\
\text { (2017 est.) }\end{array}$ & $\begin{array}{l}\text { GDP (PPP) } \\
\text { US\$ Billion } \\
\text { (2017 est.) }\end{array}$ & $\begin{array}{l}\text { GDP per } \\
\text { capita } \\
\text { US\$ } \\
\text { (2017 est.) }\end{array}$ & $\begin{array}{l}\text { School life } \\
\text { expectancy }\end{array}$ & Male & Female & $\begin{array}{c}\text { Literacy } \\
\text { rate } \\
15 \& \\
\text { over } \%\end{array}$ & Male & Female & $\begin{array}{l}\text { Education } \\
\text { expenditures } \\
\% \text { of GDP }\end{array}$ & $\begin{array}{c}\text { Urban } \\
\text { population } \\
\%(2020)\end{array}$ & $\begin{array}{c}\text { Urbanization } \\
\text { rate } \% \\
(2015-2020)\end{array}$ \\
\hline Benin & $11,612,983$ & 25.39 & 2300 & 13 (2016) & 14 & 11 & $42.4(2018)$ & 54 & 31.1 & $4(2016)$ & 48.4 & 3.89 \\
\hline Burkina Faso & $19,199,732$ & 35.85 & 1900 & 9 (2017) & 9 & 9 & $41.2(2018)$ & 50.1 & 32.7 & $4.2(2015)$ & 30.6 & 4.99 \\
\hline Cabo Verde & 560,899 & 3.777 & 7000 & $12(2017)$ & 12 & 12 & $86.8(2015)$ & 91.7 & 82 & $5.2(2017)$ & 66.7 & 1.97 \\
\hline Cote d'Ivoire & $25,659,816$ & 97.16 & 3900 & $10(2016)$ & 11 & 9 & $47.2(2018)$ & 53.7 & 40.5 & $5.1(2017)$ & 51.7 & 3.38 \\
\hline Gambia & $2,051,363$ & 5.556 & 2600 & $9(2010)$ & 9 & 9 & $50.8(2015)$ & 61.8 & 41.6 & $2.1(2016)$ & 62.6 & 4.07 \\
\hline Ghana & $27,499,924$ & 134 & 4700 & $12(2017)$ & 12 & 11 & $76.6(2015)$ & 82 & 71.4 & 3.6 (2017) & 57.3 & 3.34 \\
\hline Guinea & $11,534,306$ & 27.97 & 2200 & 9 (2014) & 10 & 8 & $30.4(2015)$ & 38.1 & 22.8 & $2.2(2017)$ & 36.5 & 3.54 \\
\hline Guinea-Bissau & $1,788,610$ & 3.171 & 1900 & .. &.. & .. & $59.9(2015)$ & 71.8 & 48.3 & $2.1(2013)$ & 44.2 & 3.41 \\
\hline Liberia & $4,689,021$ & 6.112 & 1300 & .. & .. & .. & $48.3(2017)$ & 62.7 & 34.1 & $3.8(2017)$ & 52.1 & 3.41 \\
\hline Mali & $17,885,245$ & 41.22 & 2200 & 7 (2015) & 8 & 7 & $35.5(2018)$ & 46.2 & 25.7 & $3.1(2016)$ & 43.9 & 4.86 \\
\hline Mauritania & $3,758,571$ & 17.28 & 4500 & 8 (2017) & 8 & 8 & $53.5(2017)$ & 63.7 & 43.4 & $2.6(2016)$ & 55.3 & 4.28 \\
\hline Niger & $20,391,729$ & 21.86 & 1200 & $6(2017)$ & 7 & 6 & $19.1(2015)$ & 27.3 & 11 & 3.5 (2017) & 16.6 & 4.27 \\
\hline
\end{tabular}




\section{Continued}

\begin{tabular}{|c|c|c|c|c|c|c|c|c|c|c|c|c|}
\hline Nigeria & $198,346,055$ & 1,121 & 5900 & $9(2011)$ & 9 & 8 & $62(2018)$ & 71.3 & 52.7 & .. & 52 & 4.23 \\
\hline Saint Helena & 7828 & 0.0311 & 7800 & .. & .. &.. & .. & .. & .. & .. & 40.1 & 0.73 \\
\hline Sierra Leone & $6,163,195$ & 11.55 & 1600 & .. & .. & .. & $43.2(2018)$ & 51.6 & 39.8 & $4.6(2017)$ & 42.9 & 3.12 \\
\hline Togo & $7,965,055$ & 12.97 & 1700 & 13 (2017) & 14 & 11 & $63.7(2015)$ & 77.3 & 51.2 & $5(2016)$ & 42.8 & 3.76 \\
\hline Total/Ave. & $373,782,854$ & $1,608.147$ & 4302 & & & & & & & & & \\
\hline
\end{tabular}

Source: Source: Compiled and computed based on data in the 2020 CIA World Factbook (https://www.cia.gov/library/publications/the-world-factbook/). Population data from the United States Census Bureau, 2017

(https://www.census.gov/data-tools/demo/idb/region.php?T=6\&RT=0\&A=both\&Y=2017\&C=AF\&R=110). Note: Data for Mayotte are from the 2010 World Factbook (2010 population estimates and 2005 GDP and GDP per capita data) and Reunion from the 2006 World Factbook (2006 population estimates and 2005 GDP and GDP per capita data). France has combined the data for these two nations with the population of France. Saint Helena (GDP and GDP per capita data for FY09/10 est.).

\section{Appendix A. Geographic Breakdowns of the Five Regions of Africa}

Africa $(\mathrm{n}=58)$

Eastern Africa $(n=20)$ : Burundi, Comoros, Djibouti, Eritrea, Ethiopia, Kenya, Madagascar, Malawi, Mauritius, Mayotte, Mozambique, Reunion, Rwanda, Seychelles, Somalia, South Sudan, Tanzania, Uganda, Zambia, and Zimbabwe.

Middle Africa ( $\mathrm{n}=9$ ): Angola, Cameroon, Central African Republic, Chad, Republic of Congo, Democratic Republic of Congo, Equatorial Guinea, Gabon and Sao Tome \& Principe.

Northern Africa $(n=7)$ : Algeria, Egypt, Libya, Morocco, Sudan, Tunisia and Western Sahara. Southern Africa $(n=$ 5) Botswana, Lesotho, Namibia, South Africa and Swaziland.

Western Africa ( $\mathrm{n}=17)$ : Benin, Burkina Faso, Cape Verde, Cote d'Ivoire, The Gambia, Ghana, Guinea, Guinea-Bissau, Liberia, Mali, Mauritania, Niger, Nigeria, Senegal, Sierra Leone, Togo and Saint Helena.

Source: "Composition of macro geographical (continental) regions, geographical sub-regions, and selected economic and other groupings" Retrieved on January 29, 2019 from: https://unstats.un.org/unsd/methodology/m49/. 